\title{
Magma evolution beneath Bequia, Lesser Antilles, deduced from petrology of lavas and plutonic xenoliths
}

\author{
Michal Camejo-Harry ${ }^{1,2}$ (1) $\cdot$ Elena Melekhova ${ }^{2} \cdot$ Jon Blundy ${ }^{2} \cdot$ William Attridge $^{2} \cdot$ Richard Robertson $^{1}$. \\ Thomas Christopher ${ }^{1,3}$
}

Received: 28 March 2018 / Accepted: 11 July 2018 / Published online: 5 September 2018

(c) The Author(s) 2018

\begin{abstract}
Extrusive and intrusive igneous rocks represent different parts of a magmatic system and ultimately provide complementary information about the processes operating beneath volcanoes. To shed light on such processes, we have examined and quantified the textures and mineral compositions of plutonic and cumulate xenoliths and lavas from Bequia, Lesser Antilles arc. Both suites contain assemblages of iddingsitized olivine, plagioclase, clinopyroxene and spinel with rare orthopyroxene and ilmenite. Mineral zoning is widespread, but more protracted in lavas than xenoliths. Plagioclase cores and olivine have high anorthite $(\mathrm{An} \leq 98)$ and low forsterite ( $\mathrm{Fo} \leq 84)$ compositions respectively, implying crystallisation from a hydrous mafic melt that was already fractionated. Xenolith textures range from adcumulate to orthocumulate with variable mineral crystallisation sequences. Textural criteria are used to organize the xenoliths into six groups. Amphibole, notably absent from lavas, is a common feature of xenoliths, together with minor biotite and apatite. Bulk compositions of xenoliths deviate from the liquid line of descent of lavas supporting a cumulate origin with varying degrees of reactive infiltration by evolved hydrous melts, preserved as melt inclusions in xenolith crystals. Volatile saturation pressures in melt inclusions indicate cumulate crystallization over a 162-571 MPa pressure range under conditions of high dissolved water contents (up to $7.8 \mathrm{wt} \% \mathrm{H}_{2} \mathrm{O}$ ), consistent with a variety of other thermobarometric estimates. Phase assemblages of xenoliths are consistent with published experimental data on volatile-saturated low-magnesium and high-alumina basalts and basaltic andesite from the Lesser Antilles at pressures of 200-1000 MPa, temperatures of $950-1050{ }^{\circ} \mathrm{C}$ and dissolved $\mathrm{H}_{2} \mathrm{O}$ contents of $4-7 \mathrm{wt} \%$. Once extracted from mid-crustal mushes, residual melts ascend to higher levels and undergo $\mathrm{H}_{2} \mathrm{O}$-saturated crystallization in shallow, preeruptive reservoirs to form phenocrysts and glomerocrysts. The absence of amphibole from lavas reflects instability at low pressures, whereas its abundance in xenoliths testifies to its importance in mid-crustal differentiation processes. A complex, vertically extensive (6 to at least $21 \mathrm{~km}$ depth) magmatic system is inferred beneath Bequia. Xenoliths represent fragments of the mush incorporated into ascending magmas. The widespread occurrence of evolved melts in the mush, but the absence of erupted evolved magmas, in contrast to islands in the northern Lesser Antilles, may reflect the relative immaturity of the Bequia magmatic system.
\end{abstract}

Keywords Lesser Antilles $\cdot$ Bequia $\cdot$ Grenadines $\cdot$ Xenoliths $\cdot$ Cumulates $\cdot$ Amphibole

Communicated by Othmar Müntener.

Electronic supplementary material The online version of this article (https://doi.org/10.1007/s00410-018-1504-z) contains supplementary material, which is available to authorized users.

Michal Camejo-Harry

michal.camejo@gmail.com

1 The University of the West Indies Seismic Research Centre, St. Augustine, Trinidad and Tobago

2 School of Earth Sciences, University of Bristol, Wills Memorial Building, Bristol BS8 1RJ, UK

3 Montserrat Volcano Observatory, Flemmings, Montserrat

\section{Introduction}

Magma generation at volcanic arcs is driven by interaction between slab-derived materials and the mantle. Conventional models of subduction zone magmagenesis emphasise percolation of sediment-derived partial melts and hydrous fluids from the slab into the mantle wedge, driving partial melting (Arculus 1994; Pearce and Peate 1995). An alternative view of magma formation suggests that a mélange of sediments and fluid already exists at the top of the slab, rising as diapirs into the mantle, whereupon they undergo 
partial melting to form arc magmas (Nielsen and Marschall 2017). Regardless of the ultimate origin of arc magmas, subsequent intra-crustal differentiation significantly modifies parental melts on their way to the surface. Reconstructing magmatic processes from the erupted volcanic rock record alone can be problematic since eruptions tend to sample (and blend) discrete parts of the magmatic system.

The more accessible volcanic rock record is heavily biased towards melt-rich extrusive rocks. While useful for providing information on pre- and syn-eruptive processes, their melt-dominated character limits what they can tell us about the differentiation history of parental primary, mantle-derived melts. High-pressure phase assemblages within cumulate-textured plutonic xenolith blocks, however, have a greater preservation potential than phenocrysts in lavas and are more likely to provide insight into the true fractionation history of the magmas (Arculus and Wills 1980; Macdonald et al. 2000). Studying these complimentary extrusive and intrusive (xenolith) rock archives in conjunction provides a powerful means for reconstruction of the processes operating in arc magmatic systems and the driving forces behind eruptions.

Remarkable features of the Lesser Antilles arc are both its diversity of magma compositions within a close spatial context (Brown et al. 1977) and the abundance of erupted plutonic xenoliths (Arculus and Wills 1980; Lewis 1973).
We exploit these characteristics through a detailed petrological, mineralogical and geochemical study of lavas and their xenoliths from the island of Bequia, Grenadines. This follows similar studies conducted on neighbouring islands, Grenada (Stamper et al. 2014a) and St. Vincent (Tollan et al. 2011), that highlighted the need to establish magma storage conditions beneath the intervening Grenadines archipelago.

\section{Geological setting}

The Lesser Antilles is an intra-oceanic arc resulting from the westward subduction $\left(\sim 2 \mathrm{~cm} \mathrm{a}^{-1}\right)$ of the North and South American plates beneath the Caribbean plate (Fig. 1a). The current arc is approximately $750 \mathrm{~km}$ long and comprises islands Saba to Grenada that contain 21 potentially active volcanoes (Lindsay et al. 2005). Various criteria (seismicity, magma production rates, rock types) have been used to segment the arc, with lava chemistry proving the most difficult to categorize systematically (Macdonald et al. 2000). Brown, et al. (1977) found a chemical variation along the arc that required the presence of more than one magma series. However, more recent studies on individual islands have identified a number of local magmatic lineages suggesting that grouping Lesser Antilles rocks based solely on major element chemistry may mask complexities in magmagenesis
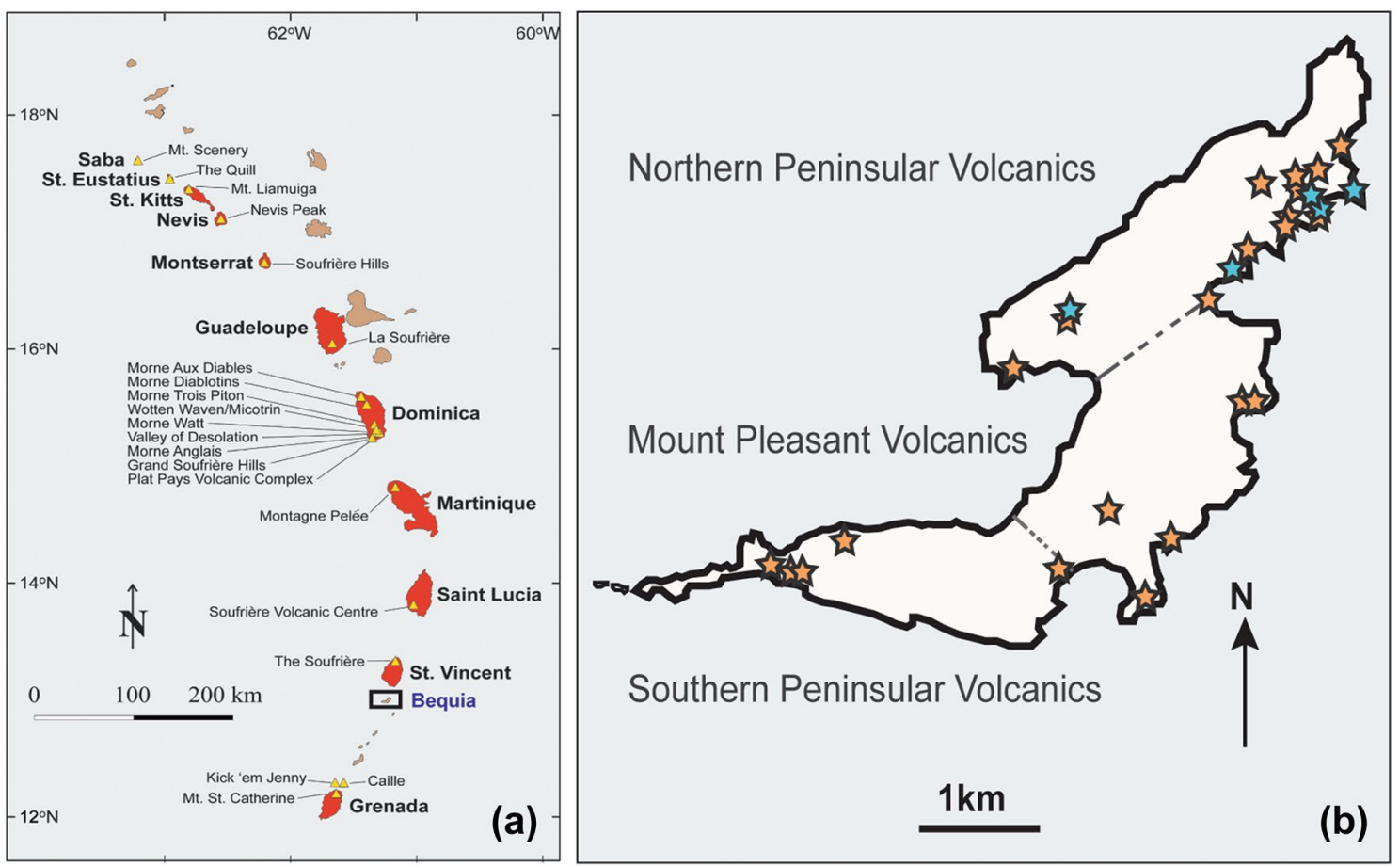

Fig. 1 a Lesser Antilles arc region showing the location of the main volcanic centres considered active or potentially active (shown as yellow triangles). b Geological map of Bequia showing identified forma- tions (after Westercamp et al. 1985) and sampling locations (orange stars—lava; blue stars—xenoliths) 
(Heath et al. 1998; Howe et al. 2015; Stamper et al. 2014a; Toothill et al. 2007). Geophysical studies (Arnaiz-Rodriguez and Orihuela 2013; Boynton et al. 1979; Christeson et al. 2008; Kopp et al. 2011) reveal a strongly layered crust with a mean thickness of $29 \mathrm{~km}$ and pronounced mid-crustal discontinuities at depths of 2-20 km that vary along strike of the arc. The scale of compositional and structural variation is clearly seen towards the south of the arc from St. Vincent to Grenada, including the Grenadines archipelago. These islands span a distance of only $140 \mathrm{~km}$, yet significant differences have been documented in their magma source and storage conditions. Experiments on primitive basalts from Grenada (Stamper et al. 2014a) and St. Vincent (Melekhova et al. 2015; Pichavant et al. 2002b) have determined the source in the mantle wedge is located at a greater depth beneath Grenada than St. Vincent (Stamper et al. 2014a). Little is known about the middlemost Grenadines, prompting a need to determine whether along-arc variations in this arc section are discrete or gradational.

Bequia is the northernmost and second largest island of the Grenadines. Volcanic activity occurred during the Pliocene with the extrusion of basaltic to andesitic lavas cut by dykes (5.0-3.5 Ma Briden et al. 1979). Three formations have been identified, corresponding to sequential phases of sometimes concurrent volcanism (Fig. 1b): Southern Peninsular $(\approx 4-5 \mathrm{Ma})$, Northern Peninsular $(\approx 4.5-3.5 \mathrm{Ma})$ and Mount Pleasant $(\approx 5 \mathrm{Ma}$ ) formations (Westercamp et al. 1985). These are interbedded with heterolithic debris flows throughout the island. Isotopic work on Bequia lavas has distinguished two suites: isotopically homogeneous suite (IHS) and isotopically diverse suite (IDS), the former interpreted to have undergone no crustal assimilation and the latter abundant sediment interaction from the Guyana Shield (Smith et al. 1996). The two suites are, however, petrographically very similar and show no systematic geographical or temporal distribution on the island. Plutonic xenoliths have also been studied in some detail (Attridge 2013; Hasanie 2000), with their isotopic variation successfully linked to the IHS and IDS lavas (Munday et al. 2000). It has not yet been shown how, or if at all, the textural and compositional features of cumulate xenoliths are related to their extrusive counterparts and how similar/different the Bequia magmatic system is to St Vincent and Grenada.

\section{Analytical techniques}

Major element concentrations of minerals and melt inclusions (MI) were analysed on polished, carbon-coated thin sections with a Cameca SX100 electron microprobe at the University of Bristol. Mineral analytical conditions comprised a $20 \mathrm{kV}$ accelerating voltage, $10 \mathrm{nA}$ beam current and $1 \mu \mathrm{m}$ spot size. Ferric iron contents were estimated using the stoichiometric methods of Droop (1987) for spinel and clinopyroxene, and Holland and Blundy (1994) for hornblende. $\mathrm{MI}$ analytical conditions comprised a $5 \mu \mathrm{m}$-defocused spot, $4 \mathrm{nA}$ beam current and $20 \mathrm{kV}$ accelerating voltage, to minimize the migration of alkalis during analysis (Humphreys et al. 2006). Both techniques were calibrated using oxide, mineral and metal standards.

Volatile $\left(\mathrm{H}_{2} \mathrm{O}\right.$ and $\left.\mathrm{CO}_{2}\right)$ concentrations in $\mathrm{MI}$ were analyzed on gold-coated polished thin sections by secondary ion mass spectrometry (SIMS) using the Cameca IMS4f instrument at the NERC ion-microprobe facility, University of Edinburgh. On any one $\mathrm{MI}, \mathrm{CO}_{2}\left(\right.$ as $\left.{ }^{12} \mathrm{C}^{+}\right)$was measured first, followed by $\mathrm{H}_{2} \mathrm{O}\left(\right.$ as $\left.{ }^{1} \mathrm{H}^{+}\right)$. Instrument conditions comprised a nominal $10 \mathrm{kV}^{16} \mathrm{O}^{-} 2-5 \mathrm{nA}$ primary beam focused to an $\sim 10 \mu \mathrm{m}$ spot on the sample surface. Positive secondary ions were extracted at $4.5 \mathrm{kV}$ with an energy offset of $50 \mathrm{eV}$ for $\mathrm{CO}_{2}\left(75 \mathrm{eV}\right.$ for $\left.\mathrm{H}_{2} \mathrm{O}\right)$ and a $25 \mu \mathrm{m}$ image field. ${ }^{12} \mathrm{C}^{+}$data were obtained at high mass resolution to eliminate ${ }^{24} \mathrm{Mg}^{2+}$ interference. Volatile species were calibrated against basaltic glass standards using data analysis procedures of Blundy and Cashman (2005).

Whole rock major and trace elements were analysed by X-ray fluorescence spectrometry (XRF) using a Bruker AXS S4 Pioneer instrument at the University of East Anglia. Samples were crushed and powdered using the rock splitter, jaw crusher and planetary ball mill at the University of Bristol. Pressed pellets and glass beads for analysis were prepared at the University of East Anglia.

\section{Xenolith petrology}

The studied plutonic xenoliths were obtained as ex situ deposits from heterolithic debris flows in the northern part of the island (Fig. 1b) during a 2011 field campaign. The mineralogy of the xenoliths consists mainly of olivine, plagioclase, clinopyroxene, calcic amphibole, spinel, ilmenite and rare orthopyroxene with apatite and biotite as accessory phases. Olivine is commonly partially to completely iddingsitized with few instances of unaltered grains in any one sample. Other phases are generally alteration-free. Plagioclase is the only ubiquitous phase in every sample.

A total of 50 xenoliths were collected and studied in thin section. Most samples comprise grains ranging from 2 to $5 \mathrm{~mm}$. Some samples are very coarse grained and/or porphyritic (6-20 mm grains) while 5\% of the sample set are wholly microcrystalline $(<500 \mu \mathrm{m})$. A variety of cumulate textures are observed from adcumulate, mesocumlate to orthocumulate according to the nomenclature of Wager, et al. (1960). Zoning and resorption textures are abundant.

The crystallization sequence of each xenolith was determined by textural observations of included and interstitial phases. The order of phase crystallization is 
variable throughout the xenolith suite with some samples having more than one generation of plagioclase and spinel (Table 1). A notable feature is the late appearance of olivine in some sequences (Fig. 3a-c). The only consistent feature is the crystallisation of plagioclase before clinopyroxene with the exception of a single plagioclase-free clinopyroxene + amphibole xenolith variety.

Samples were point-counted (900-1800 points per sample) using a mechanical stage and the volume modes were used to classify the xenoliths using the scheme of Steckeisen (1976) (Table 1). Volume modes were converted to mass modes using mineral densities (Deer et al. 2013) (Fig. 2a). Textural features were used to organize the xenoliths into six groups (1-6) that are further subdivided (a, b, c, etc.) on the basis of the observed mineral assemblages and crystallisation sequences (Fig. 4; Table 2).

\section{Group 1 hornblende-free (ol + plag + cpx + spl + ilm)}

This group is distinguished by mesocumulate/orthcumulate textures lacking amphibole (Fig. 4a). Olivine is partially to completely iddingsitized, with few instances of iddingsitized cores within unaltered rims. Olivine $(\phi \leq 4 \mathrm{~mm})$ and clinopyroxene $(\phi \leq 5 \mathrm{~mm})$ grains are anhedral making up 13 and $30 \%$ by mass respectively. Plagioclase grains (57-78\%) are generally subhedral and sieve-textured, but may be anhedral when observed as inclusions. Plagioclase grains are mostly $2 \mathrm{~mm}$ in size, except where there is more than one generation, early crystallising plagioclase occurs as small rounded inclusions $(\phi<500 \mu \mathrm{m})$ in other minerals while the later generation may reach up to $8 \mathrm{~mm}$, with sutured grain contacts. Spinel and ilmenite generally occur as inclusions, but spinel may in some cases occur interstitially. Zoning occurs in all phases, however, in some olivine gabbros plagioclase is unzoned. The principal crystallisation sequences are: $1 \mathrm{a}-$ plag $>$ ol $>$ cpx; $1 \mathrm{~b}-\mathrm{ol}>$ plag $>$ cpx .

\section{Group 2 euhedral clinopyroxene (ol + plag + cpx \pm hbl \pm spl)}

This group is characterised by euhedral ( $\phi \leq 5 \mathrm{~mm}$ ) clinopyroxene (comprising up to $40 \%$ ) that is absent from all other xenolith groups (Fig. 4b). Textures are adcumulate and mesocumulate. Olivine (13\%) is anhedral $(\phi \leq 3 \mathrm{~mm})$ and partially to completely iddingsitized. Plagioclase $(47 \%)$ is subhedral with sieve-textured cores. Plagioclase grain sizes are chiefly $2 \mathrm{~mm}$, but where there is more than one generation, the later generation may reach up to $5 \mathrm{~mm}$. Amphibole (3\%), if present, has subhedral poikilitic textures. Spinel when present occurs as minor inclusions. Zoning is pervasive. The principal crystallisation sequences are: $2 \mathrm{a}-$ plag $>$ ol $>$ cpx $>$ hbl; $2 \mathrm{~b}-\mathrm{ol}>$ plag $>$ cpx .

\section{Group 3 prismatic hornblende (ol + plag + cpx + hbl + spl \pm ilm)}

The majority (45-61\%) of grains are prismatic adcumulate amphiboles exhibiting $120^{\circ}$ grain boundaries (Fig. 4c). Interstitial phases are rare, occurring in only one sample as a second generation of spinel. Grain size differences are observed with samples being completely microcrystalline $(\phi \leq 500 \mu \mathrm{m})$ or extremely coarse $(\phi \leq 20 \mathrm{~mm})$. Some samples are porphyritic. Olivine $(<2 \%)$, when present, is heavily iddingsitized, anhedral and always microcrystalline. Plagioclase (29-46\%) is subhedral with sieve-textured cores. Clinopyroxene (up to $12 \%$ ) grains are usually subhedral and only present as completely rounded inclusions in hornblende. Ilmenite is only observed in microcrystalline samples. Zoning is prevalent. The principal crystallisation sequences are: $3 \mathrm{a}-$ plag $>$ ol $>$ cpx $>$ hbl; $3 \mathrm{~b}-$ plag $>$ cpx $>$ hbl; $3 \mathrm{c}-$ ol $>$ plag $>$ cpx $>$ hbl; $3 \mathrm{~d}-\mathrm{ol}>$ plag $>$ hbl.

\section{Group 4 subhedral poikilitic hornblende $($ plag $+c p x+h b l+s p l \pm o l \pm i l m \pm b t \pm a p \pm o p x)$}

Subhedral poikilitic hornblende with inclusions of one or more minerals (particularly rounded plagioclase and spinel) is dominant (up to 56\%) (Fig. 4d). Plagioclase (48\%) is subhedral $(\phi \leq 2 \mathrm{~mm})$ with sieve textures; clinopyroxene $(<15 \%)$ is subhedral or anhedral $(\varnothing \leq 500 \mu \mathrm{m})$. Iddingsitized olivine, biotite, apatite, orthopyroxene and ilmenite occur in one sample (BQA10); spinel is the opaque oxide component of the other members of this group. Zoning is widespread, but most pronounced in sample BQA10. The principal crystallisation sequences are: $4 \mathrm{a}-\mathrm{plag}>\mathrm{cpx}>\mathrm{hbl}$; $4 b-$ plag $>$ ol/opx $>$ hbl.

\section{Group 5 interstitial hornblende (ol + plag + cpx + opx + hbl + spl + ilm)}

This group exhibits one of two textural patterns: either (a) minor interstitial amphibole displaying alteration of clinopyroxene to amphibole along grain edges and as blebs along cleavage planes (Fig. 4e) or (b) large expanses of poikilitic amphibole plates $(\phi \leq 12 \mathrm{~mm})$. Textures are orthocumulate. Interstitial glass is observed, albeit generally partially crystallised. Olivine $(<10 \%)$ is anhedral $(\varnothing \leq 3 \mathrm{~mm})$, with a combination of iddingsitized and unaltered grains, the former sometimes existing as iddingsitized patches within unaltered olivine grains. Plagioclase (38-80\%) is subhedral $(\phi \leq 2 \mathrm{~mm})$ with sieve-textured cores. Clinopyroxene (5-36\%) is anhedral $(\phi \leq 2 \mathrm{~mm}$ ) and poikilitic. Of all xenolith groups, orthopyroxene is most significant here $(<11 \%)$ with grain sizes $<500 \mu \mathrm{m}$. Zoning is prevalent. The principal crystallisation sequences 


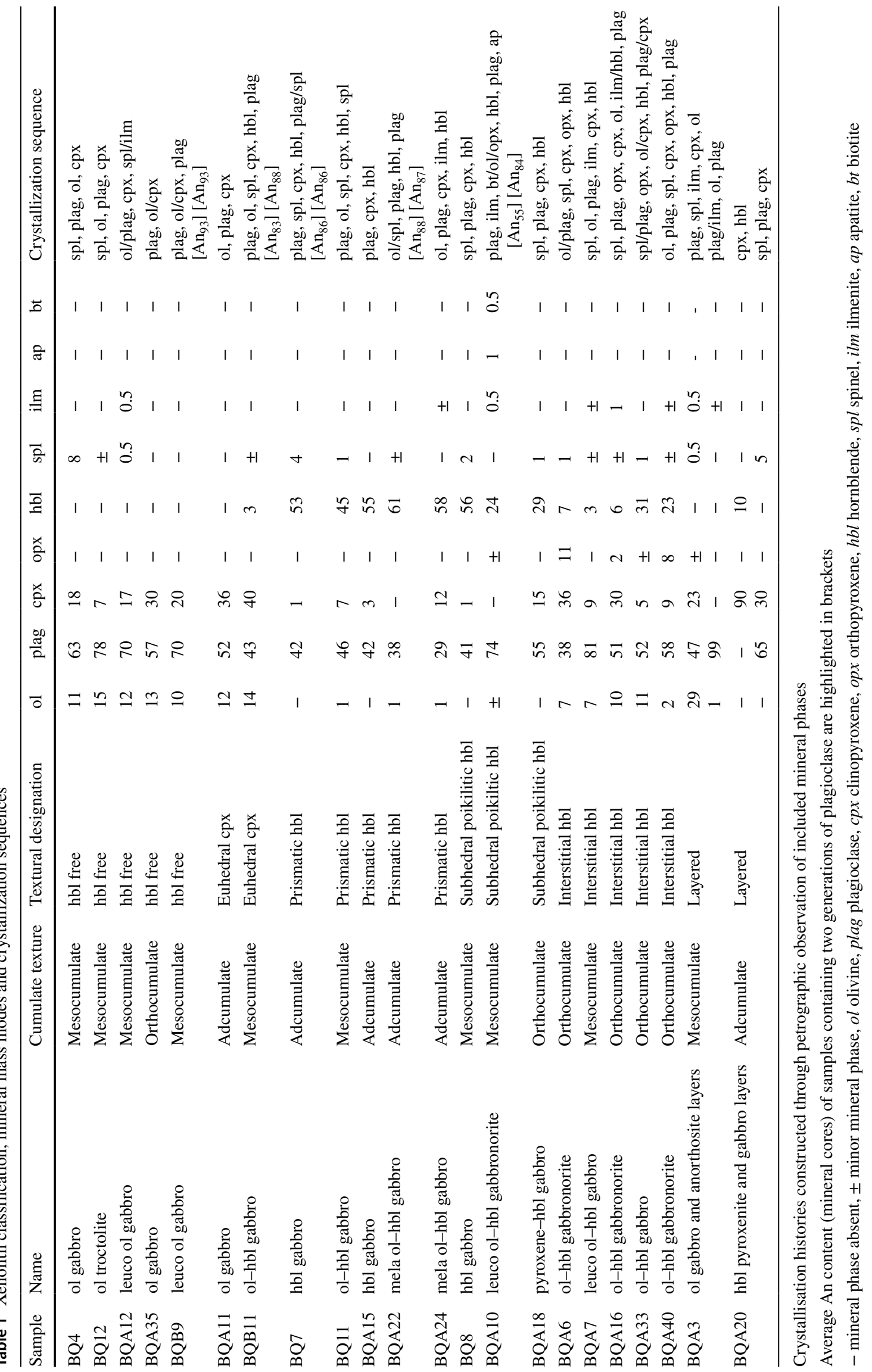




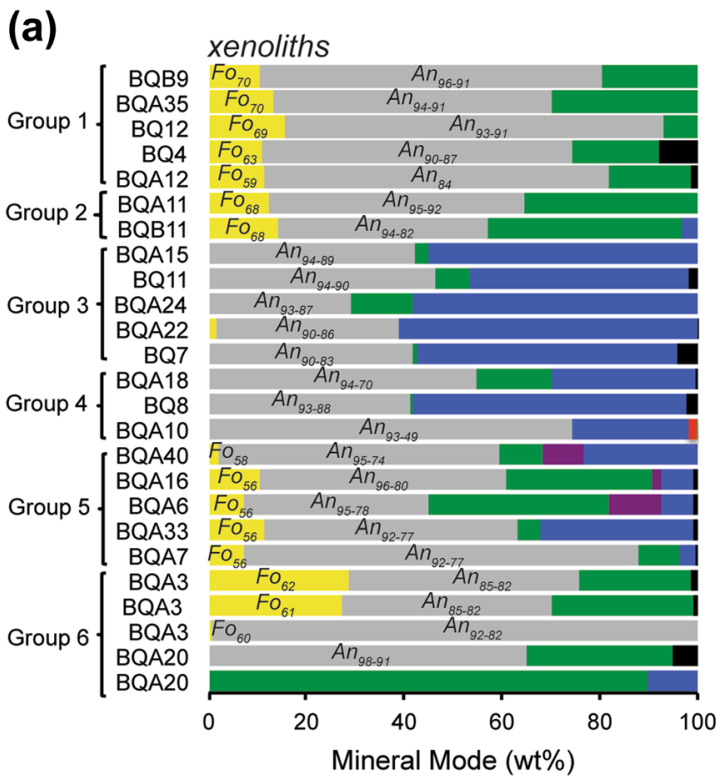

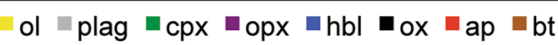

Fig. 2 Modal phase proportions (by mass) of phases in Bequia rocks: a xenoliths b phenocrysts and c glomerocrysts. Note that glomerocrysts phase proportions and assemblages are averages per sample. Sample numbers and textural group/rock type designations are given. Average olivine Fo contents and core/rim plagioclase An contents are

are: $5 \mathrm{a}-$ plag $>$ ol $>\mathrm{cpx}>\mathrm{hbl} ; 5 \mathrm{~b}-\mathrm{ol}>\mathrm{plag}>\mathrm{cpx}>\mathrm{hbl} ; 5 \mathrm{c}-$ ol $>$ plag $>$ cpx $>$ opx $>$ hbl; 5d-plag $>$ opx $>$ cpx $>$ ol $>$ hbl.

\section{Group 6 layered $($ ol + plag + cpx + opx + hbl + spl + ilm)}

This group is unique in that it consists of distinct layering on a microscopic scale (Fig. 4f). Layers differing by texture, grain size and/or mineral assemblage are juxtaposed in any one thin section. Unaltered poikilitic olivine (28\%) is observed in one sample (BQA3, Fig. 3a), which is not observed in any other textural group. Members of this group contain at least one monomineralic layer (anorthosite, BQA3 or pyroxenite, BQA20), which is again absent from other textural groups. Sieve textured plagioclase is a recurring feature. Zoning is prevalent. Sample BQA20 (Group 6c) is unique in containing disrupted layers of a plagioclase-free clinopyroxene + amphibole assemblage surrounded by a gabbroic matrix of plagioclase, clinopyroxene and spinel (Fig. 4f). The principal crystallisation sequences are: $6 \mathrm{a}-\mathrm{plag}>\mathrm{cpx}>\mathrm{ol}$; $6 \mathrm{~b}-\mathrm{plag}>\mathrm{ol}$; $6 \mathrm{c}-\mathrm{cpx}>\mathrm{hbl} ; 6 \mathrm{~d}-\mathrm{plag}>\mathrm{cpx}$.

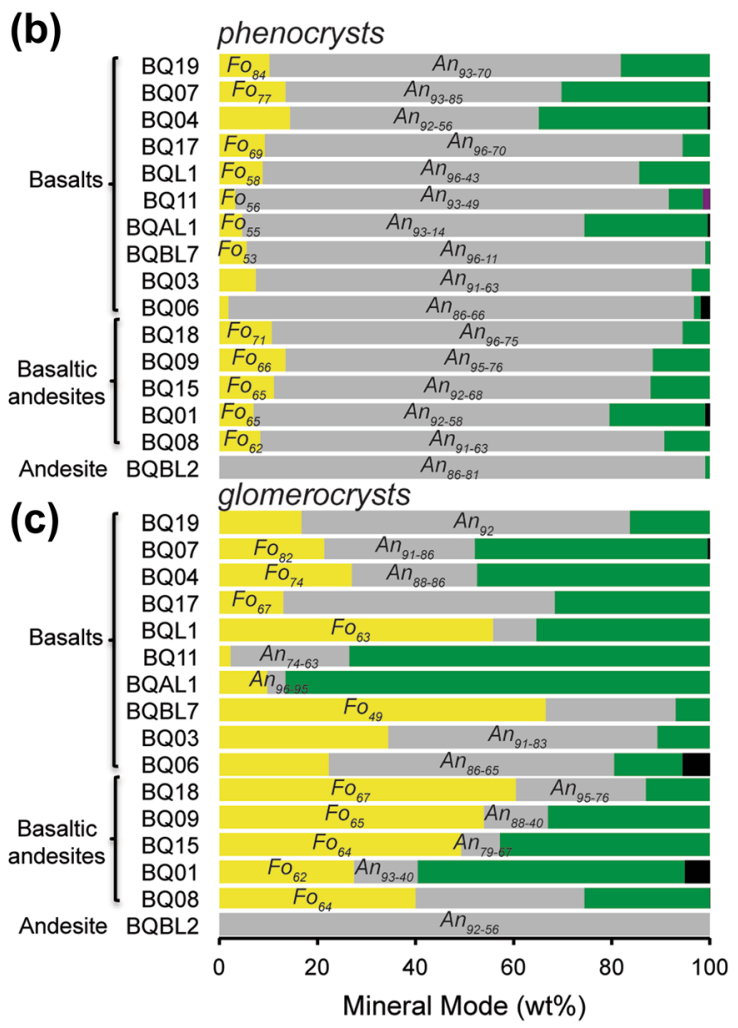

shown for each sample. Fo compositions are not listed where olivine is highly altered. Samples are listed in order of decreasing Fo content of olivine followed by An content of plagioclase within a given group. For lavas, compositional ranges are provided for both phenocrysts and glomerocrysts where possible

\section{Hornfelsed xenoliths}

A few xenolith samples (BQA20, BQA40), irrespective of their textural group designation, exhibit mortar or granoblastic textures with some instances of mineral alteration (Figure A1, Online Resource 1). Closely interlocking, fine-grained crystals comprise gabbroic lithologies. Mineral alteration is mainly observed in pyroxene grains by their unusual deep green appearance in plane-polarized light. Such textures may be related to high-temperature metamorphic reactions as a vestige of direct wall-rock interaction. There is no mineralogical or chemical evidence to warrant the hornfelsed xenoliths being placed in a separate group.

\section{Lava petrology}

Sixteen lava samples, collected during fieldwork in 2011 and 2015, were studied (Fig. 1b). The lava suite consists of basalts, basaltic andesites and a single andesite with glomeroporphyritic textures. Phenocryst assemblages consist of olivine, plagioclase and clinopyroxene with minor 
Table 2 Summary of xenolith groups and subdivisions

\begin{tabular}{|c|c|c|}
\hline Group & Textural designation & $\begin{array}{l}\text { Main assemblages } \\
\text { and crystallisation } \\
\text { sequences }\end{array}$ \\
\hline 1 & Hornblende-free & $\begin{array}{l}\text { a. plag, ol, cpx } \\
\text { b. ol, plag, cpx }\end{array}$ \\
\hline 2 & Euhedral clinopyroxene & $\begin{array}{l}\text { a. plag, ol, cpx, hbl } \\
\text { b. ol, plag, cpx }\end{array}$ \\
\hline 3 & Prismatic hornblende & $\begin{array}{l}\text { a. plag, ol, cpx, hbl } \\
\text { b. plag, cpx, hbl } \\
\text { c. ol, plag, cpx, hbl } \\
\text { d. ol, plag, hbl }\end{array}$ \\
\hline 4 & Subhedral poikilitic hornblende & $\begin{array}{l}\text { a. plag, cpx, hbl } \\
\text { b. plag, ol/opx, hbl }\end{array}$ \\
\hline 5 & Interstitial hornblende & $\begin{array}{l}\text { a. plag, ol, cpx, hbl } \\
\text { b. ol, plag, cpx, hbl } \\
\text { c. ol, plag, cpx, opx, hbl } \\
\text { d. plag, opx, cpx, ol, hbl }\end{array}$ \\
\hline 6 & Layered & $\begin{array}{l}\text { a. plag, cpx, ol } \\
\text { b. plag, ol } \\
\text { c. cpx, hbl } \\
\text { d. plag, cpx }\end{array}$ \\
\hline
\end{tabular}

orthopyroxene, spinel and ilmenite. Amphibole is notably absent. Phenocryst mass modes for the lavas were calculated on a vesicle-free basis (Fig. 2b). Phenocryst aggregates (glomerocrysts) are ubiquitous. They occur as both monomineralic and polymineralic clusters with two or more grains, the latter occurring only in basalts and basaltic andesites (Fig. 2c). Melt inclusions (MI) are lacking in phenocrysts. Secondary minerals prehnite and calcite occupy veins and vesicles, suggesting host lava flows were affected by low-temperature metamorphism after emplacement. The groundmass consists of microlites of the phenocryst and microphenocryst minerals. The basalts and basaltic andesites are generally phenocryst- and microphenocryst-rich, with the groundmass making up $<50 \%$ vol. of the rocks. Conversely, the andesite is phenocryst-poor with $>60 \%$ vol groundmass.

\section{Olivine}

Almost all olivine phenocrysts and microphenocrysts are partially to completely replaced by iddingsite. In some cases, groundmass olivine shows iddingsitization. Olivine can be both subhedral and anhedral, and occurs in sizes ranging from a few hundreds of micrometres to $2.5 \mathrm{~mm}$. Phenocrysts exhibit various stages of corrosion from being partially embayed to complete dissolution of interiors. Olivine is generally the first phase to crystallize, however, rounded inclusions of other phases (plagioclase (Fig. 5d) and clinopyroxene) within poikilitic olivine were observed in some samples suggesting an additional, later generation of olivine.
Fig. 3 Backscattered electron images of crystallisation sequences in xenoliths. a Poikilitic olivine with inclusions of plagioclase and clinopyroxene (BQA3, ol gabbro layer). b Olivine with inclusions of plagioclase, together with a later generation of plagioclase imposing growth on olivine (BQA3, anorthosite layer). c Olivine with orthopyroxene and plagioclase inclusions and clinopyroxene with plagioclase inclusions (BQA16). d Large plagioclase grains with sutured contacts, together with clinopyroxene with plagioclase inclusions (BQB9)
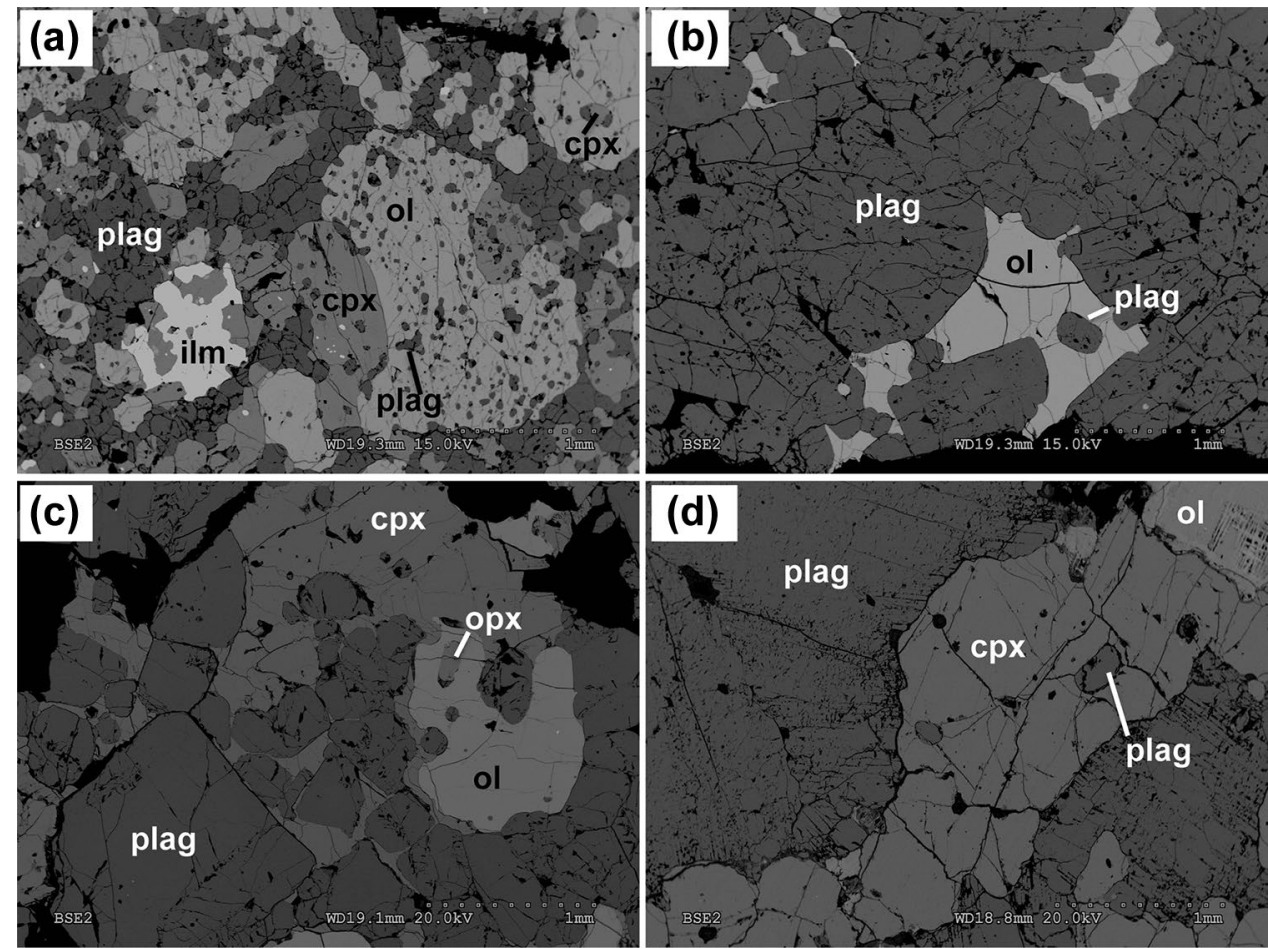

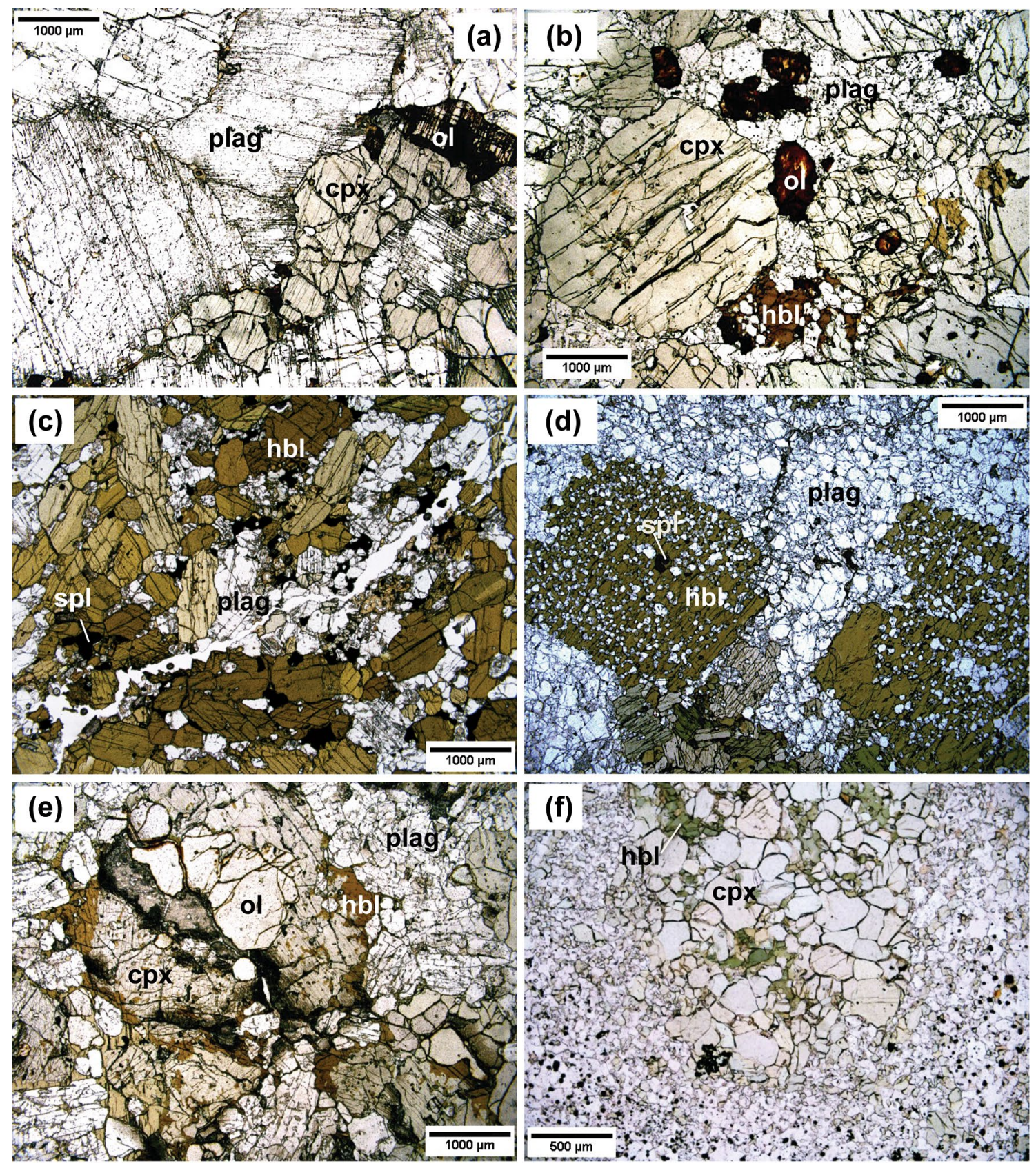

Fig. 4 Photomicrographs (plane polarized light, $\mathrm{ppl}$ ) of representative xenolith groups. a Group 1 containing anhedral, interlocking iddingsitized olivine, plagioclase and clinopyroxene with two generations of plagioclase observed as inclusions in clinopyroxene and large grains with sutured contacts (BQB9). b Group 2 with zoned euhedral clinopyroxene, anhedral iddingsitized olivine, subhedral sieve-textured plagioclase and minor poikilitic amphibole (BQB11). c Group 3 dom-

\section{Plagioclase}

Plagioclase grain sizes range from a few hundred micrometres up to $3 \mathrm{~mm}$. Individual grains are euhedral to subhedral. Twinning and zoning are widespread. Corrosion

inated by early crystallising prismatic amphibole (BQ11). d Group 4 containing subhedral poikilitic amphibole with rounded inclusions of plagioclase and spinel (BQ8). e Group 5 containing intercumulus amphibole with unaltered olivine (BQA8). f Group 6 with clinopyroxene-amphibole cluster surrounded by a microcrystalline adcumulate of plagioclase, clinopyroxene and spinel (BQA20)

of the interior and exterior of grains is a common feature with grains having sieve textures and being partially embayed respectively. Two texturally dominant plagioclase types are distinguished: zoned phenocrysts and unzoned microphenocrysts. 
Fig. 5 Photomicrographs of representative lava textures. a Basalt (cross polarized light, xpl) containing a small glomerocryst with grains protruding into groundmass (BQ10). b Basalt (xpl) with a small glomerocryst containing grains a few hundreds of micrometres or less (BQ01). c Andesite (ppl) with abundant plagioclase grains with vesicles and trachytic textured groundmass (BQBL2). d Basalt (ppl) containing olivine grains with plagioclase inclusions (BQ03)
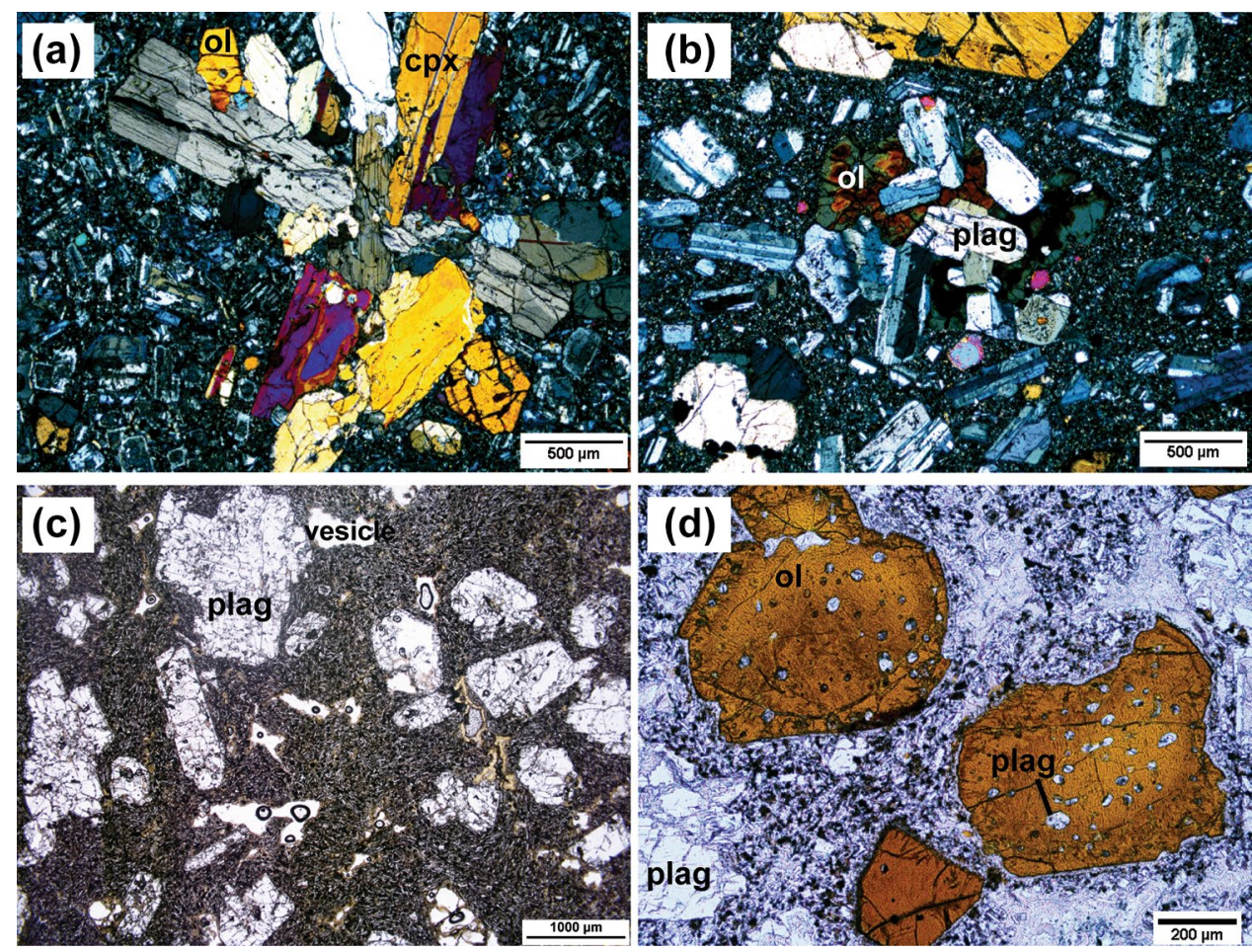

\section{Pyroxene}

Clinopyroxene sizes range from several hundreds of micrometres to $\leq 1 \mathrm{~cm}$, with grains being euhedral to subhedral. Occasionally, one or more grain boundaries are fractured. Twinning and zoning (concentric and sector) are common. Plagioclase inclusions are observed suggesting crystallisation before clinopyroxene. Three textural types of pyroxene are distinguished: large, isolated zoned megacrysts; zoned and unzoned phenocrysts; and unzoned microphenocrysts. Subhedral orthopyroxene $(<2 \mathrm{~mm})$ is a minor, unzoned phenocryst $(<2 \%)$ in a single sample (BQ11).

\section{Opaque oxides}

Spinel tends to occur as a minor component of glomerocrysts and in the groundmass. Ilmenite is rare, confined to two basalts (BQ04 \& BQ07). Both types of oxide have homogenous textures.

\section{Glomerocrysts}

Polymineralic glomerocryst sizes range from a few hundred micrometres to $1 \mathrm{~cm}$. Assemblages includes spl-ol-plag-cpx, ol-plag, ol-plag-cpx, plag-cpx and ol-cpx (Fig. 5a, b). Amphibole and orthopyroxene are notably absent. Monomineralic (plagioclase) clusters dominate the andesitic sample (Fig. 5c). Plagioclase-only ( $\phi \leq 2 \mathrm{~mm}$ ) and clinopyroxene-only ( $\phi \leq 3 \mathrm{~mm}$ ) clots are also observed in basaltic samples. Minerals exhibit similar disequilibrium textures, such as zoning and resorption to those in phenocrysts. Crystals from all cluster types protrude out into the groundmass indicating that they were not rock fragments but loose aggregates of crystals when entrained into the host magma (Seaman 2000). Interstitial glass is absent.

\section{Xenolith mineral chemistry}

Xenolith mineral compositions are presented in Table A1 (Online Resource 2). Mg\# is always expressed as $100 \mathrm{Mg} /$ $\left(\mathrm{Mg}+\mathrm{Fe}^{2+}\right)$ with $\mathrm{Fe}^{2+}$ determined by stoichiometry or via the method of Holland and Blundy (1994) for amphibole.

Olivine is present in the majority of the xenoliths studied $(\approx 75 \%)$. Forsterite contents range from $\mathrm{Fo}_{71-55}$. NiO concentrations are generally below detection, with only the layered group displaying detectable concentrations from 0.08 to $0.14 \mathrm{wt} \%$. CaO concentrations vary from 0.09 to $0.31 \mathrm{wt} \%$ with no clear correlation with Fo (Fig. 6). Conversely, Fo contents correlate negatively with $\mathrm{MnO}$ (0.7 to $0.4 \mathrm{wt} \%)$. Zoning could not be reliably measured due to iddingsite alteration along grain rims.

Plagioclase $\left(\mathrm{An}_{98-49}\right)$ is a ubiquitous xenolith phase. Normal zoning is dominant with rimward decreases in An from 


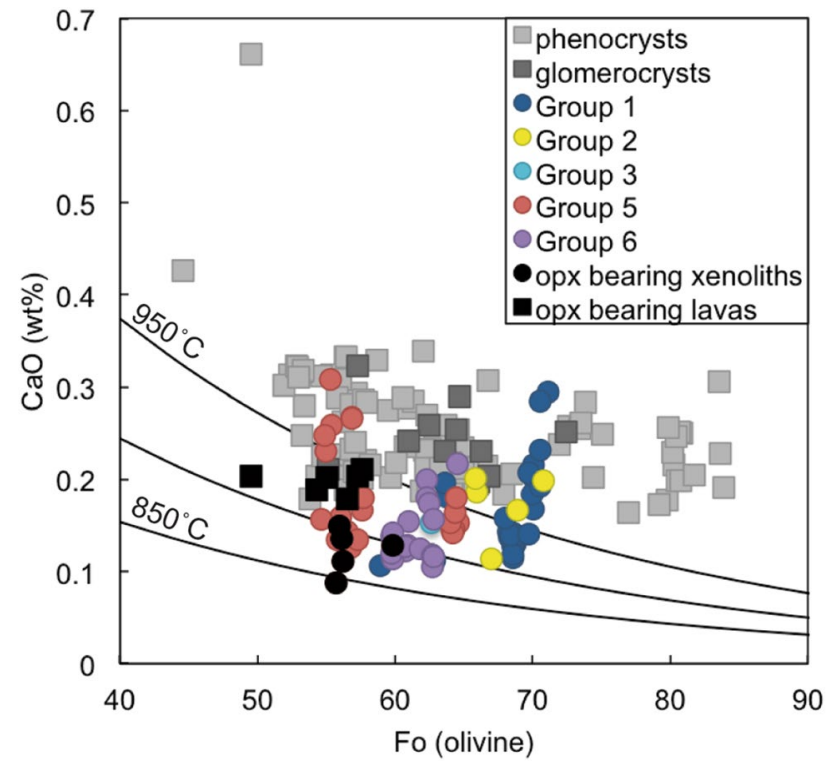

Fig. 6 Variation in olivine composition for xenoliths and lavas. Xenoliths are denoted by circles and lavas by squares. Note the preferential clustering of xenolith groups and the similarity in glomerocryst and xenolith Fo compositions. $\mathrm{CaO}$ content lower in xenoliths than lavas, denoting calcium diffusing out of olivine during cooling. Isotherms calculated from the olivine-clinopyroxene thermometer of Shejwalkar and Coogan (2013) for orthopyroxene-bearing xenoliths and lavas

1 to $34 \%$. BQA10 shows an extreme rimward decrease of $\mathrm{An}_{83}-\mathrm{An}_{49}$. Reverse zoning is less prevalent with rimward increases in $\mathrm{An} \leq 2 \%$ (e.g. $\mathrm{An}_{91}$ to $\mathrm{An}_{93}$ in BQA35). Where there is more than one generation of xenolith plagioclase, the average An content either does not vary considerably between the two generations or shows higher An contents in the larger, later grains (e.g. BQA10 and BQB11, Table 1).

Clinopyroxene $\left(\mathrm{Mg} \#_{97-70}\right)$ is present in all xenoliths except BQA10, that contains a single orthopyroxene grain, and BQA22. All grains are zoned showing normal $(\leq 12 \%$ $\mathrm{Mg \#}$ decrease), reverse ( $\leq 5 \% \mathrm{Mg \#}$ increase) or oscillatory zoning. Compositions consist mainly of diopside and salite. With increasing $\mathrm{Mg \#}, \mathrm{Al}^{(\mathrm{IV})}$ and $\mathrm{Ca}$ (pfu) (Fig. 7) contents increase while $\mathrm{Ti}(\mathrm{pfu})$ decreases. Group 1 contains a subset of highly magnesian ( $\mathrm{Mg \#} \mathrm{>90)} \mathrm{clinopyroxenes} \mathrm{(from}$ sample BQB9) that plot separately from the rest of the suite. These grains also exhibit normal and reverse zoning.

Orthopyroxene (Mg\# $\left.{ }_{68-56}\right)$ is present in 5\% of the samples analyzed. When occurring with amphibole, orthopyroxene compositions are $\mathrm{En}_{64-55}$. The clinopyroxene-free sample (BQA10) has an orthopyroxene composition $\left(\mathrm{En}_{55}\right)$ distinct from the other clinopyroxene-bearing xenoliths $\left(\mathrm{En}_{64-61}\right)$. Orthopyroxene in the amphibole-free xenolith (Group 1) is more Fe-rich $\left(\mathrm{En}_{66}\right)$, lying instead closer to lava compositions.

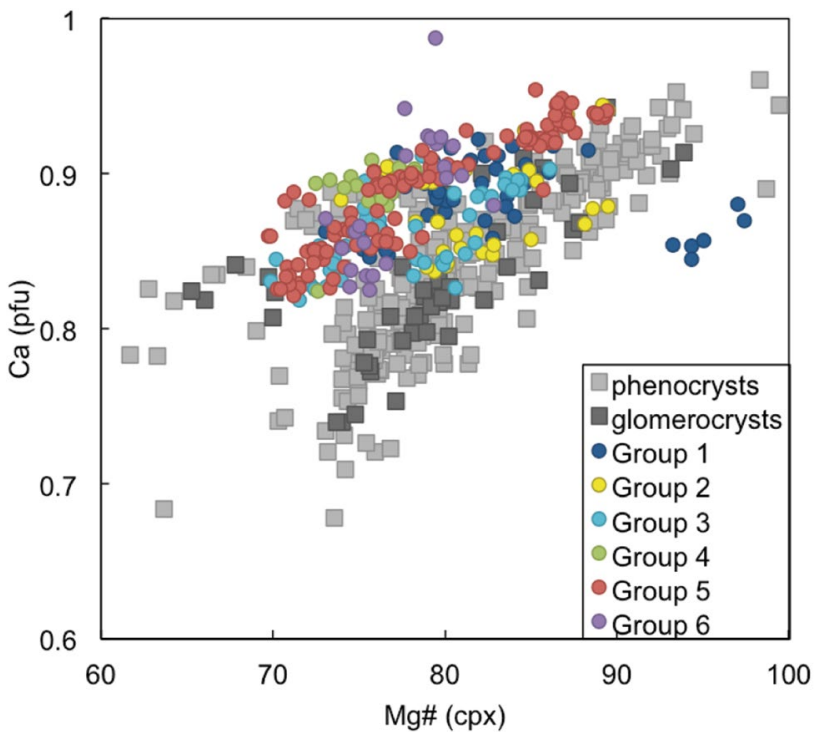

Fig. 7 Variation in clinopyroxene compositions for xenoliths and lavas in terms of $\mathrm{Ca}$ atoms per formula unit versus $\mathrm{Mg \#}$. Two divergent trends of decreasing $\mathrm{Ca}$ content with decreasing $\mathrm{Mg \#}$ are observed for clinopyroxene phenocrysts and glomerocryts. Note high $\mathrm{Mg \#}(\geq 90)$ clinopyroxene in xenoliths from Group 1 and some lavas

Calcic amphibole $\left(\mathrm{Mg}_{98-60}\right)$ with pargasite composition (Leake et al. 2003) is present in just over half of the xenoliths analyzed. Normal zoning is observed ( $\leq 5 \% \mathrm{Mg} \#)$. Texturally, three types of amphibole were identified: (a) early crystallizing prismatic grains and late crystallizing (b) poikilitic and (c) interstitial grains (Fig. 4c, d, e). Amphiboles corresponding to the different textural groups define distinct compositions clustering in terms of $\mathrm{K}, \mathrm{Al}^{\mathrm{IV}}$ and $\mathrm{Ti}$ versus

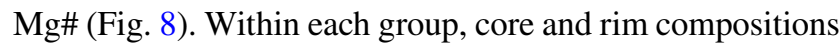
often overlap. Low Mg\# amphiboles from Group 4 (BQA10) contain unusually high $\mathrm{K}$ contents $(>0.14 \mathrm{pfu}$ ) compared to other textural groups. In fact, Group 4 contains two distinct compositions distinguished by $\mathrm{Mg \#}$. The lower $\mathrm{Mg} \#$ cluster belongs to a single sample (BQA10), whereas the remaining samples exhibit higher Mg\#. Group 5 exhibits two clusters separated by K contents: higher K concentrations belong to BQA33 and BQA16, while the remainder of the samples in this group contain lower $\mathrm{K}$ concentrations. A subset of amphiboles has notably high $\mathrm{Al}^{\mathrm{IV}}$ contents ( $>2 \mathrm{pfu}$ ). $\mathrm{Cr}$ contents are generally below detection except in some amphiboles from Groups 2 and 6 (0.03-0.05 pfu). Group 2 contains subhedral poikilitic-textured hornblende with compositions matching the rest of those in Group 4. Extremely high $\mathrm{Mg} \#$ amphibole, distinct from the other textural groups, occurs in Group 6.

Spinel is present in more than $75 \%$ of the xenoliths studied, though never exceeding $>8 \%$ by mode. In terms of $\mathrm{Cr} \#=\mathrm{Cr} / \mathrm{Cr}+\mathrm{Al}$, compositions range from Cr-rich spinel to titaniferous magnetite. The most $\mathrm{Cr}$-rich spinels $\left(\mathrm{Cr} \#_{52-44}\right)$ 

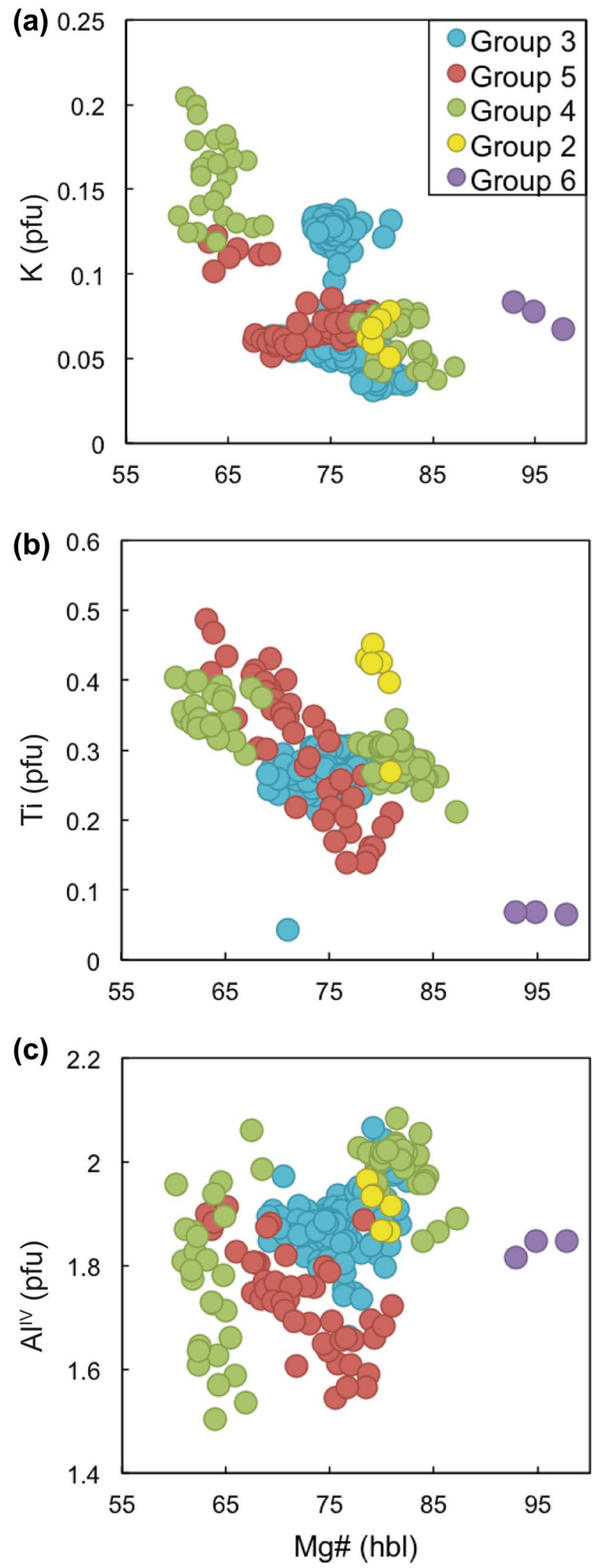

Fig. 8 Variation in hornblende composition for plutonic xenoliths in terms of a $\mathrm{K}(\mathrm{pfu}), \mathbf{b} \mathrm{Ti}(\mathrm{pfu})$ and $\mathbf{c} \mathrm{Al}^{\mathrm{IV}}$ (pfu) versus $\mathrm{Mg \#}$. Note the wide range in $\mathrm{Mg \#}$ and compositional grouping of xenolith groups are observed in Groups 1b, 2a, 6a and 6b (Figure A2, Online Resource 3), occurring generally as inclusions in olivine or plagioclase. Interestingly, the rest of Group 6 contains $\mathrm{Cr}$-poor spinels $(\mathrm{Cr} \#=<10)$ from the hornfelsed sample BQA20.

\section{Lava phenocryst chemistry}

Phenocryst mineral compositions are presented in Table A1 (Online Resource 2).

Olivine crystals exhibit a broader range of compositions $\left(\mathrm{Fo}_{84-45}\right)$ than the xenoliths. Olivine in glomerocryst clusters has a Fo range that closely mirrors the xenoliths. The extent of normal zoning (when measurable) is at most a 7\% Fo decrease towards the rim $\left(\mathrm{Fo}_{65}\right.$ to $\mathrm{Fo}_{58}$, BQL1). Reverse zoning is also observed, e.g. $\mathrm{Fo}_{55}$ to $\mathrm{Fo}_{57}$ in $\mathrm{BQL1}$. All phenocrysts contain $>0.15 \mathrm{wt} \% \mathrm{CaO}$ (Fig. 6). $\mathrm{MnO}$ steadily decreases with increasing Fo from 1 to $0.2 \mathrm{wt} \%$. NiO contents are generally below detection except at $\mathrm{Fo}_{\geq 80}$, where they reach up to $0.13 \mathrm{wt} \%$.

Plagioclase shows a broad range of compositions $\left(A n_{96-11}\right)$. However, the lowest An compositions $\left(<A n_{30}\right)$ are rare (Table A1, Online Resource 2); the majority of analyses have a range of $\mathrm{An}_{96-40}$. Plagioclases exhibit normal and reverse zoning with oscillatory zoning common. The extent of normal zoning is up to a $46 \%$ An decrease towards the $\operatorname{rim}\left(\mathrm{An}_{89}\right.$ to $\left.\mathrm{An}_{43}, \mathrm{BQL1}\right)$. The extent of reverse zoning was found to be at most a $15 \%$ An increase rimward $\left(\mathrm{An}_{63}\right.$ to $\left.\mathrm{An}_{74}, \mathrm{BQ} 11\right)$. The most calcic plagioclase compositions were found in the cores of zoned crystals; lowest An contents were found in rims.

Clinopyroxene $\left(\mathrm{Mg \#}_{98-60}\right)$ phenocrysts comprise diopside, salite and high-Ca augite compositions. Normal zoning occurs in all textural types, with core and rim compositions averaging $\mathrm{Mg \#}{ }_{85}$ and $\mathrm{Mg \#}{ }_{77}$ respectively. Reverse zoning is restricted to glomerocrysts, isolated megacrysts and large phenocrysts. Clinopyroxene $\mathrm{Ca}$ content increases with increasing $\mathrm{Mg \#}$ reaching a maximum of $0.96 \mathrm{pfu}$ at $\mathrm{Mg \#}_{98}$. Phenocrysts and glomerocrysts display two clear trends: low-Ca and high-Ca (Fig. 7). Clinopyroxene shows a trend of increasing $\mathrm{Al}^{\mathrm{IV}}$ and decreasing $\mathrm{Ti}$ (pfu) with increasing

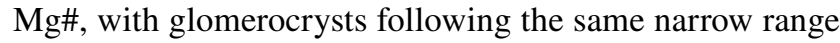
in $\mathrm{Mg \#}$ displayed by the xenoliths.

Orthopyroxene $\left(\mathrm{Mg}_{70-69}\right)$ was found only in BQ11 (Fig. 2b) and lacks obvious zoning.

Spinel is predominantly titaniferous magnetite ( $\leq 2 \%$ by mode). Anomalous $\mathrm{Cr}$-rich spinels $\left(\mathrm{Cr}_{77-58}\right)$ are found in two samples as rounded inclusions in olivine and as anhedral microphenocrysts (Figure A2, Online Resource 3). 


\section{Xenolith melt inclusions}

Melt inclusions (MI), ranging in size from $<10$ to $50 \mu \mathrm{m}$, occur in most phases except orthopyroxene, biotite and apatite. Those in plagioclase are often devitrified. MI have a pale brown colour in transmitted light and vary in shape from rounded to oval. While many contain a vapour bubble, some are bubble-free. Such bubbles may contain substantial concentrations of $\mathrm{CO}_{2}$ which may result in underestimates of the original dissolved $\mathrm{CO}_{2}$ (Moore et al. 2015). We selected for analysis twelve large ( $\geq 30 \mu \mathrm{m}$ in diameter) glassy, daughter mineral-free MI (Table 3).

MI EPMA totals are $\geq 90.5 \mathrm{wt} \%$. MI record low $\mathrm{Kd}_{\mathrm{Fe}-\mathrm{Mg}}$ values when compared to expected $\mathrm{Kd}$ values (Table 3) for olivine (Roeder and Emslie 1970), clinopyroxene and hornblende (calculated using St. Kitts experiment Run 3-1, Melekhova et al. 2017) suggestive of post-entrapment crystallization (PEC). Corrections for PEC, made using experimental Kd values from Melekhova et al. (2017), ranged from 1 to $8 \%$. Corrected and uncorrected MI compositions are reported in Table 3. Corrected MI compositions, normalised to $100 \%$ anhydrous, vary from 63.6 to $69.8 \mathrm{wt} \% \mathrm{SiO}_{2}$ and 0.6 to $2 \mathrm{wt} \% \mathrm{MgO}$ (Fig. 9). Their distribution describes a trend that extends to beyond the highest $\mathrm{SiO}_{2}$ contents of the bulk lavas. $\mathrm{MI}$ are depleted in $\mathrm{FeO}$ and $\mathrm{TiO}_{2}$ (Figure A3, Online Resource 4), as expected for greater degrees of fractionation. There is no relationship between MI composition and xenolith group or MI host. The most evolved melt is a clinopyroxene-hosted MI from Group 3.

$\mathrm{MI} \mathrm{H}_{2} \mathrm{O}$ and $\mathrm{CO}_{2}$ concentrations, as measured by SIMS, range from 2.8 to $7.8 \mathrm{wt} . \%$ and 55 to $2405 \mathrm{ppm}$, respectively (Table 3). Volatile contents were not affected significantly by PEC. Again, there is no obvious correlation between MI $\mathrm{H}_{2} \mathrm{O}$ content and host mineral or xenolith group. The MI with the highest $\mathrm{H}_{2} \mathrm{O}$ content was found in a clinopyroxene grain from sample BQA35. Chlorine contents range from 1000 to 3900 ppm; sulphur contents are generally below detection $(<382 \mathrm{ppm})$.

\section{Whole rock compositions}

Bulk rock major element compositions of the plutonic xenoliths were calculated using averaged mineral compositions and mass fraction modes. Where olivine compositions could not be accurately measured due to alteration, calculations were not attempted. Five xenoliths were analysed using XRF (as for lavas) to check the accuracy of xenolith bulk rock calculations (Table 4). Generally, good agreement ( $\geq 97 \%$ relative agreement) is observed for the two methods with the exception of sample BQA35. In this case we infer that the effects of mineral zoning and the sample's heterogeneity contributed to this mismatch. This was checked by conducting a mass balance calculation to determine the strength of the relationship between the measured XRF major element data and the averaged major element compositions of the constituent minerals: olivine, plagioclase and clinopyroxene. The smallest residuals were computed when the cores and rims for plagioclase and clinopyroxene were considered separately to compute the whole rock composition. XRF whole rock data for BQA35 were used in preference to calculated bulk composition in all plots.

Lava whole rock compositions range from medium-K basalts to basaltic andesites (50-58 wt $\% \mathrm{SiO}_{2}$, Table 4). They show typical fractionation trends with decreasing $\mathrm{MgO}$, i.e. increasing $\mathrm{SiO}_{2}, \mathrm{Na}_{2} \mathrm{O}$ and $\mathrm{P}_{2} \mathrm{O}_{5}$ and decreasing $\mathrm{CaO}$ and $\mathrm{FeO}$ (Fig. 9). There is a fractionation peak in $\mathrm{Al}_{2} \mathrm{O}_{3}$ (22 wt\%) corresponding to the onset of plagioclase crystallisation. With the exception of BQA35, all xenoliths show compositions that are distinct from the liquid line of descent described by the lavas (Fig. 9) confirming that they are indeed true extractive assemblages (or cumulates) and not frozen aliquots of erupted magma. In contrast, BQA35 lies along the liquid line of descent of the lavas. This sample is denoted "non-cumulate gabbro" in Fig. 9 and likely represents magma that has solidified in situ.

\section{Comparison of xenoliths and lavas}

Several textural and compositional likenesses were observed between the plutonic xenoliths and lavas. Plagioclase is a dominant phase in both lava phenocrysts and plutonic samples but not in glomerocrysts (Fig. 2). Similar disequilibrium textures (e.g. sieve textured cores and resorption) were revealed in all suites. Zoning is ubiquitous, but generally more protracted in lava phenocrysts and glomerocrysts compared to xenoliths. The most striking difference is the ubiquity of amphibole in xenoliths and its absence in lavas. Compositional ranges in all phases are generally broader in lavas and more restricted in xenoliths. A complex growth history is, therefore, inferred for phases in both lavas and xenoliths.

\section{Olivine}

Bequia lava olivines have a wider Fo range $\left(\mathrm{Fo}_{84-45}\right)$ than their xenolith counterparts $\left(\mathrm{Fo}_{71-55}\right)$, which have very similar Fo range to glomerocrysts. Higher Fo contents in lava olivines $(F o \geq 80)$ hint toward either a more primitive parent or the incorporation of another population of olivine crystallising under different conditions just before eruption. Olivine $\mathrm{NiO}$ contents were generally below the detection limit and no relationship is observed between $\mathrm{CaO}$ and $\mathrm{Fo}$ (Fig. 6). However, xenoliths show lower $\mathrm{CaO}$ contents compared to phenocrysts and glomerocrysts suggestive of $\mathrm{Ca}$ 


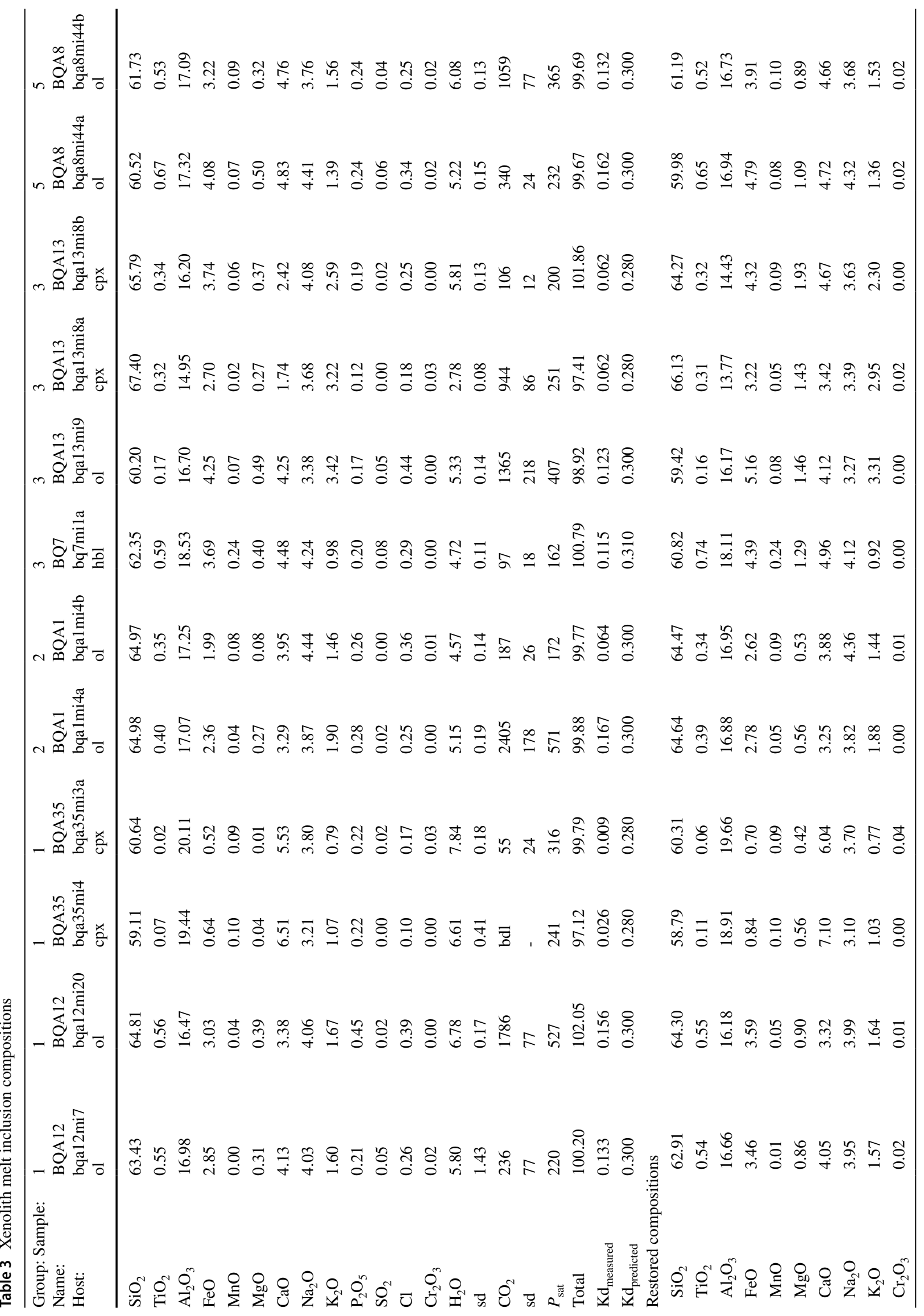


diffusion out of olivine during cooling (Kohler and Brey 1990; Shejwalkar and Coogan 2013). Isotherms calculated for orthopyroxene-bearing xenoliths using the Shejwalkar and Coogan (2013) olivine-pyroxene thermometer indicate crystallisation between 850 and $900{ }^{\circ} \mathrm{C}$, slightly lower than orthopyroxene-bearing lava olivines $\left(900-950{ }^{\circ} \mathrm{C}\right)$. Higher $\mathrm{Ca}$ contents in phenocryst olivines may also suggest that the magmas from which they crystallised contained lower $\mathrm{H}_{2} \mathrm{O}$ concentrations than those of cumulates (Gavrilenko et al. 2016), which may in turn reflect differences in the pressures of crystallisation.

\section{Plagioclase}

Anorthite ranges are notably broad in both lava (phenocrysts: predominantly $\mathrm{An}_{96-40}$ and glomerocrysts: $\mathrm{An}_{96-41}$ ) and xenolith $\left(\mathrm{An}_{98-49}\right)$ plagioclase. Lava phenocryst and glomerocryst cores lie in the range $\mathrm{An}_{96-86}$ and $\mathrm{An}_{96-76}$, respectively, whereas xenolith cores are $\mathrm{An}_{98-84} \cdot \mathrm{K}_{2} \mathrm{O}$ concentrations decrease with increasing An, however, the majority of lava concentrations range up to $0.5 \mathrm{wt} \%$ (with $<2 \%$ of rim analyses range 1.7-5 wt \%) while xenolith concentrations range up to only $0.3 \mathrm{wt} \%$.

\section{Clinopyroxene}

Clinopyroxene zoning occurs in lavas and xenoliths, however, it is more common in glomerocrysts. While clinopyroxene grains tend to be euhedral/subhedral in lavas, xenolith clinopyroxene is generally anhedral except for those in Group 2. Lava clinopyroxene has diopside, salite and high$\mathrm{Ca}$ augite compositions, whereas xenoliths mainly cluster around diopside and salite. The $\mathrm{Mg \#}$ ranges for phenocrysts, glomerocrysts and xenoliths are $\mathrm{Mg}_{98-60}, \mathrm{Mg}_{93-66}$ and $\mathrm{Mg \#}_{97-70}$ respectively. The variation in $\mathrm{Ca}(\mathrm{pfu})$ with $\mathrm{Mg} \#$ (Fig. 7) highlights two trends likely reflecting the control of temperature on $\mathrm{Ca}$. The first trend displayed by lavas and xenoliths shows higher $\mathrm{Ca}$ contents suggesting lower crystallisation temperatures. The second trend, denoted by a second population of lavas and fewer xenoliths, contains lower Ca suggestive of higher crystallisation temperatures. Lower temperatures in xenoliths are consistent with intratelluric cooling prior to entrainment. It is also conceivable that the diverging $\mathrm{Ca}$ trends indicate small variations in the $\mathrm{H}_{2} \mathrm{O}$ contents of the magmas from which different clinopyroxene populations crystallised. At depth, higher $\mathrm{H}_{2} \mathrm{O}$ contents decrease crystallisation temperatures (and silica activity) leading to clinopyroxene compositions with higher $\mathrm{Ca}$ contents (Müntener et al. 2001). Phenocrysts from lavas and glomerocrysts show similar distribution and variation in $\mathrm{Ca}$ and $\mathrm{Mg \#}$. 

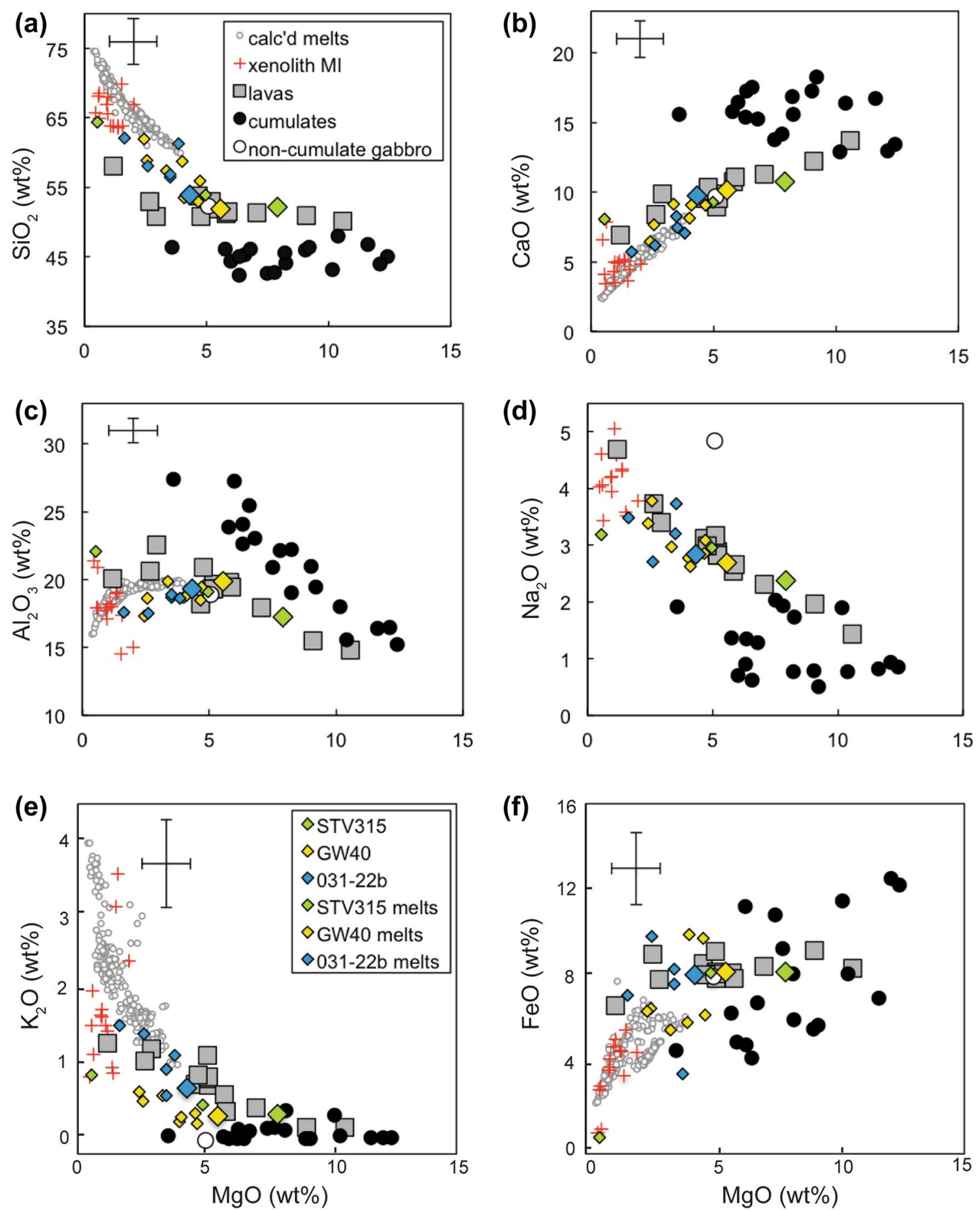

Fig. 9 Bulk major element variations in Bequia xenoliths (estimated from mineral modes and compositions), xenolith MI (EPMA, corrected for PEC) and lavas (XRF). Melt compositions in equilibrium with cumulate calcic amphibole are also displayed (with associated error bars highlighted), calculated using chemometric equations of Zhang, et al. (2017). Note overlap between calculated melts and MI. The starting compositions of three Lesser Antilles experimental stud-

ies (031-22b, STV315, GW40) from Pichavant et al. 2002a, Pichavant and Macdonald 2007 and Pichavant et al. 2018 are shown by big diamonds. Chemical composition of experimental melts from these studies in equilibrium with solid residues shown on Fig. 12 are plotted as small diamonds for comparison with Bequia liquid line of decent. See text for discussion 
Table 4 Normalized (to 100\%) xenolith and lava compositions (wt $\%$ oxides) estimated from mineral modes and XRF respectively

\begin{tabular}{|c|c|c|c|c|c|c|c|c|c|c|c|c|}
\hline Group & Sample & $\mathrm{SiO}_{2}$ & $\mathrm{TiO}_{2}$ & $\mathrm{Al}_{2} \mathrm{O}_{3}$ & $\mathrm{FeO}$ & $\mathrm{MnO}$ & $\mathrm{MgO}$ & $\mathrm{CaO}$ & $\mathrm{Na}_{2} \mathrm{O}$ & $\mathrm{K}_{2} \mathrm{O}$ & $\mathrm{P}_{2} \mathrm{O}_{5}$ & $\mathrm{Cr}_{2} \mathrm{O}_{3}$ \\
\hline \multirow[t]{8}{*}{1} & BQ4 & 42.40 & 0.96 & 22.67 & 11.34 & 0.14 & 6.15 & 15.40 & 0.91 & 0.01 & - & 0.01 \\
\hline & BQ12 & 44.36 & 0.06 & 27.30 & 4.99 & 0.10 & 6.00 & 16.49 & 0.71 & 0.01 & - & 0.00 \\
\hline & $\mathrm{BQ} 12^{\mathrm{a}}$ & 45.26 & 0.09 & 28.34 & 4.39 & 0.09 & 5.17 & 15.78 & 0.86 & 0.01 & 0.01 & - \\
\hline & BQA12 & 46.18 & 0.50 & 23.87 & 6.32 & 0.12 & 5.76 & 15.80 & 1.36 & 0.03 & - & 0.05 \\
\hline & BQA35 & 45.81 & 0.28 & 21.21 & 5.68 & 0.11 & 8.91 & 17.28 & 0.67 & 0.02 & - & 0.03 \\
\hline & BQA35 ${ }^{\mathrm{a}}$ & 53.76 & 0.87 & 19.18 & 7.95 & 0.17 & 4.95 & 9.30 & 3.14 & 0.58 & 0.10 & - \\
\hline & BQA35 $5^{\mathrm{MB}}$ & 53.37 & 1.14 & 19.31 & 8.19 & 0.11 & 5.18 & 9.89 & 4.94 & 0.00 & 0.00 & - \\
\hline & BQB9 & 45.27 & 0.14 & 25.46 & 4.25 & 0.08 & 6.58 & 17.57 & 0.63 & 0.01 & - & 0.01 \\
\hline \multirow[t]{2}{*}{2} & BQA11 & 46.40 & 0.23 & 19.43 & 5.73 & 0.12 & 9.21 & 18.31 & 0.50 & 0.01 & - & 0.05 \\
\hline & BQB11 & 46.80 & 0.37 & 15.85 & 7.14 & 0.15 & 12.04 & 16.70 & 0.82 & 0.03 & & 0.10 \\
\hline \multirow[t]{2}{*}{3} & BQ7 & 42.64 & 1.96 & 20.89 & 10.88 & 0.15 & 7.49 & 13.79 & 2.03 & 0.15 & - & 0.02 \\
\hline & BQA15 & 44.18 & 1.57 & 22.23 & 6.00 & 0.08 & 8.25 & 15.57 & 1.73 & 0.39 & - & 0.01 \\
\hline \multirow[t]{2}{*}{4} & BQ8 & 42.80 & 1.60 & 22.15 & 9.28 & 0.12 & 7.79 & 14.16 & 1.92 & 0.15 & - & 0.02 \\
\hline & BQA18 & 45.00 & 0.94 & 24.06 & 4.83 & 0.08 & 6.34 & 17.27 & 1.34 & 0.13 & - & 0.00 \\
\hline \multirow[t]{8}{*}{5} & BQA6 & 47.94 & 0.45 & 15.57 & 8.14 & 0.18 & 10.40 & 16.39 & 0.77 & 0.04 & - & 0.12 \\
\hline & BQA7 & 46.31 & 0.43 & 26.73 & 5.06 & 0.08 & 4.01 & 15.39 & 1.93 & 0.05 & - & 0.01 \\
\hline & $\mathrm{BQA}^{\mathrm{a}}$ & 46.82 & 0.85 & 25.03 & 6.10 & 0.13 & 5.14 & 14.39 & 1.50 & 0.03 & 0.01 & - \\
\hline & BQA16 & 45.61 & 0.99 & 19.02 & 8.14 & 0.18 & 8.22 & 16.91 & 0.77 & 0.12 & - & 0.03 \\
\hline & BQA33 & 43.17 & 1.78 & 18.04 & 11.50 & 0.20 & 10.17 & 12.92 & 1.90 & 0.32 & - & 0.01 \\
\hline & BQA33 ${ }^{\mathrm{a}}$ & 46.01 & 1.04 & 20.80 & 9.56 & 0.18 & 8.29 & 12.29 & 1.57 & 0.24 & 0.02 & - \\
\hline & BQA40 & 46.37 & 0.51 & 22.84 & 6.83 & 0.13 & 6.82 & 14.99 & 1.38 & 0.11 & - & 0.00 \\
\hline & $\mathrm{BQA} 40^{\mathrm{a}}$ & 48.42 & 0.47 & 21.98 & 6.15 & 0.13 & 6.76 & 14.39 & 1.54 & 0.12 & 0.02 & - \\
\hline \multirow[t]{3}{*}{6} & BQA3 & 45.03 & 0.39 & 15.26 & 12.24 & 0.24 & 12.43 & 13.44 & 0.86 & 0.02 & - & 0.10 \\
\hline & BQA3 & 45.65 & 0.00 & 34.10 & 0.60 & 0.01 & 0.27 & 17.98 & 1.36 & 0.02 & - & 0.00 \\
\hline & BQA3 & 44.04 & 0.60 & 16.46 & 12.55 & 0.23 & 12.10 & 12.95 & 0.95 & 0.01 & - & 0.11 \\
\hline \multirow[t]{8}{*}{ Basalt } & BQ04 & 50.08 & 0.60 & 14.81 & 8.39 & 0.18 & 10.57 & 13.71 & 1.44 & 0.16 & 0.05 & - \\
\hline & BQ05 & 50.85 & 0.93 & 22.58 & 7.86 & 0.18 & 2.93 & 9.89 & 3.40 & 1.21 & 0.18 & - \\
\hline & BQ06 & 50.93 & 0.65 & 15.52 & 9.23 & 0.19 & 9.08 & 12.24 & 1.96 & 0.16 & 0.06 & - \\
\hline & BQ07 & 51.41 & 0.80 & 17.92 & 8.47 & 0.18 & 7.06 & 11.31 & 2.31 & 0.42 & 0.09 & - \\
\hline & BQ10 & 51.91 & 0.95 & 19.30 & 9.15 & 0.19 & 5.11 & 8.94 & 3.18 & 1.12 & 0.15 & - \\
\hline & BQ14 & 51.25 & 0.86 & 19.78 & 8.15 & 0.17 & 5.82 & 10.73 & 2.55 & 0.59 & 0.09 & - \\
\hline & BQ17 & 50.77 & 0.96 & 20.93 & 8.07 & 0.17 & 4.76 & 10.35 & 2.99 & 0.86 & 0.12 & - \\
\hline & BQ19 & 51.53 & 0.82 & 19.43 & 7.90 & 0.18 & 5.89 & 11.11 & 2.66 & 0.37 & 0.11 & - \\
\hline Basaltic & BQ01 & 53.73 & 1.02 & 18.22 & 8.60 & 0.21 & 4.65 & 9.58 & 3.12 & 0.73 & 0.15 & - \\
\hline \multirow[t]{4}{*}{ Andesite } & BQ08 & 52.87 & 0.88 & 19.55 & 7.92 & 0.18 & 5.18 & 9.68 & 2.89 & 0.73 & 0.12 & - \\
\hline & BQ09 & 52.22 & 0.95 & 19.63 & 8.20 & 0.18 & 5.18 & 9.91 & 2.81 & 0.80 & 0.12 & - \\
\hline & BQ15 & 52.91 & 0.94 & 19.33 & 8.14 & 0.17 & 5.19 & 9.53 & 2.83 & 0.84 & 0.12 & - \\
\hline & BQ16 & 53.02 & 1.12 & 20.61 & 9.02 & 0.19 & 2.66 & 8.43 & 3.74 & 1.05 & 0.16 & - \\
\hline Andesite & BQ18 & 58.10 & 0.71 & 20.05 & 6.67 & 0.20 & 1.19 & 6.91 & 4.69 & 1.29 & 0.20 & - \\
\hline
\end{tabular}

$M B$ mass balance calculation, - not analysed

${ }^{a} \mathrm{XRF}$ data from selected xenoliths for comparison to calculations

\section{Orthopyroxene}

Orthopyroxenes are generally distinct between lava phenocrysts and xenoliths. Orthopyroxenes in lavas span $\mathrm{Al}^{\mathrm{IV}}$ 0.04-0.06, Ca (pfu) $0.06-0.10$ and $\mathrm{Mg} \#_{70-69}$, whereas in xenoliths they span $\mathrm{Al}^{\mathrm{IV}} 0.01-0.04, \mathrm{Ca}$ (pfu) $0.04-0.06$ and $\mathrm{Mg} \#_{68-56}$. Lower Ca content of xenolith orthopyroxene is consistent with lower temperatures.

\section{Amphibole}

The presence of amphibole in xenoliths and its absence in lavas may reflect its instability at low pressures and during magma ascent. The evidence of cooling of xenolith assemblages to temperatures below lavas may also have enhanced amphibole stability. Where present, amphibole is a late phase in xenoliths, suggestive of reaction of hydrous evolved 
Table 5 Estimates of temperature, pressure and oxygen fugacity for the plutonic xenoliths

\begin{tabular}{|c|c|c|c|c|c|c|}
\hline Sample & Group & Method & Phases & $T\left({ }^{\circ} \mathrm{C}\right)$ & $\mathrm{P}(\mathrm{MPa})$ & $\underset{\text { relative to } \triangle \mathrm{NNO}}{\log f \mathrm{O}_{2}}$ \\
\hline BQA3 & 6 & Ballhaus et al. (1991) & ol-spl & $1008-1055$ & Assumed $500 \mathrm{MPa}$ & 1.31 to 1.36 \\
\hline BQA3 & 6 & Andersen and Lindsley $(1985)^{\mathrm{a}}$ & spl-ilm & $812-828$ & - & 1.15 to 1.33 \\
\hline BQB11 & 2 & & & 849 & - & 1.86 \\
\hline \multirow[t]{2}{*}{ BQA40 } & 5 & Wells (1977) & cpx-opx & $939-957$ & - & - \\
\hline & & Putirka (2008) & & $920-930$ & $800-880$ & - \\
\hline BQ7 & 3 & Holland and Blundy (1994) ${ }^{\mathrm{b}}$ & hbl-plag & $1002-1044$ & Assumed $500 \mathrm{MPa}$ & - \\
\hline BQ8 & 4 & & & $1005-1043$ & & - \\
\hline BQ11 & 4 & & & 1017 & & - \\
\hline BQA7 & 5 & & & $1008-1021$ & & - \\
\hline BQA10 & 4 & & & $623-979$ & & - \\
\hline BQA18 & 4 & & & 968 & & - \\
\hline BQA22 & 3 & & & $957-1003$ & & - \\
\hline BQA24 & 3 & & & $965-1008$ & & - \\
\hline BQA40 & 5 & & & $938-995$ & & - \\
\hline BQB11 & 2 & & & $1028-1046$ & & - \\
\hline BQA3 & 6 & Ziberna et al. $(2017)^{\mathrm{c}}$ & cpx-ol-plag & $926-945$ & $300,303,370$ & - \\
\hline BQA35 & 1 & & & $982-1051$ & $\begin{array}{l}221,315,347 \\
399,409\end{array}$ & - \\
\hline BQB9 & 1 & & & 995 & 437 & - \\
\hline BQ1 & 5 & & & $936-938$ & 322,416 & - \\
\hline BQ1 & 5 & & spl-cpx-ol-plag & - & 224,328 & - \\
\hline
\end{tabular}

${ }^{a}$ Lindsley and Spencer (1982) oxide formula recalculation

${ }^{\mathrm{b}}$ [edenite + albite $=$ richterite + anorthite $]$

${ }^{\mathrm{c}}$ Multiple reaction barometer

melts with anhydrous crystals, possibly via a percolative infiltration process (e.g. Smith 2014). Such a process would not have occurred in lavas.

\section{Spinel}

Lava and xenolith spinels exhibit chromite and titaniferous magnetite compositions, the latter being more abundant. Spinel is modally more significant in xenoliths (Fig. 2) possibly a result of density-related concentration (Arculus and Wills 1980). The variable proportions of spinel in xenoliths are reflected in the wide spread in bulk $\mathrm{FeO}$ (Fig. 9f) and $\mathrm{TiO}_{2}$ contents (Figure A3, Online Resource 4). Cr-rich spinel occurs in both lavas and xenoliths with maximum $\mathrm{Cr} \# 77$ and $\mathrm{Cr} \# 54$ respectively (Figure A2, Online Resource 3).

\section{Discussion}

\section{Geothermobarometry of plutonic xenoliths}

The storage conditions $\left(\mathrm{P}-\mathrm{T}-\mathrm{H}_{2} \mathrm{O}-\mathrm{fO}_{2}\right)$ under which the xenoliths crystallised prior to entrainment in erupted lavas

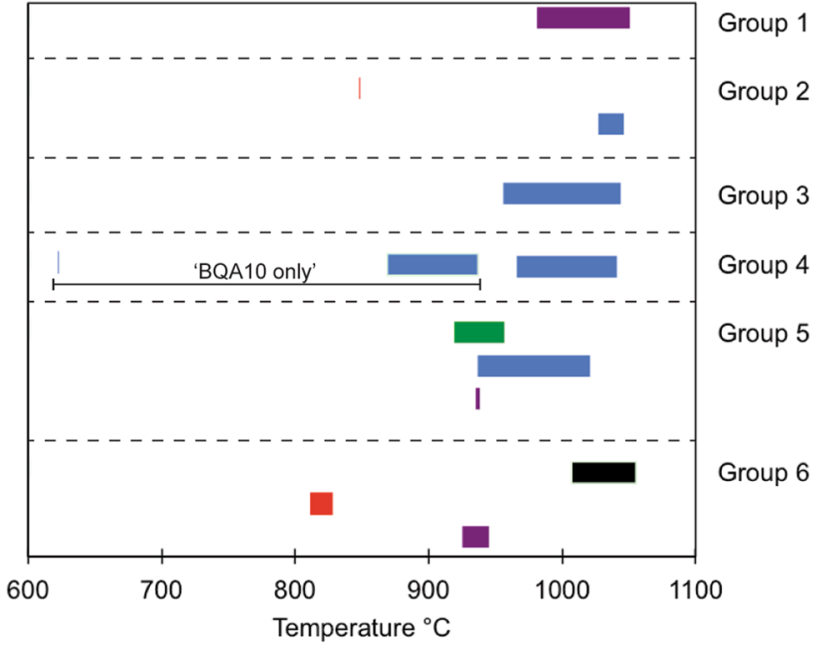

\begin{tabular}{|ll|}
\hline Ziberna et al. (2017) & andersen \& Lindsley (1985) \\
- Holland \& Blundy (1994) & m cpx-opx thermometers \\
- Ballhaus et al. (1991) &
\end{tabular}

Fig. 10 Temperature estimates of xenoliths. Temperature ranges for each geothermometer utilized are distinguished by xenolith group 
were calculated to establish the configuration of the subvolcanic system beneath Bequia. Mineral assemblages for providing reliable estimates are severely limited in lavas. Phenocrysts lack melt inclusions (MI) and significant proportions of Cr-rich spinel, ilmenite, orthopyroxene and hornblende to allow for the use of many thermobarometers. The iddingsitized nature of olivine is also a major hindrance. For these reasons we present estimates of the intensive parameters for xenolith crystallisation only, for which a wide range of methods is available.

A combination of geothermometers was applied to xenoliths (Table 5): olivine-spinel ( $\pm 92^{\circ} \mathrm{Ballhaus}$ et al. 1991), magnetite-ilmenite $\left( \pm 36^{\circ} \mathrm{C}\right.$; Andersen and Lindsley 1985), hornblende-plagioclase $\left( \pm 40{ }^{\circ} \mathrm{C}\right.$, Holland and Blundy $1994)$, clinopyroxene-orthopyroxene $\left( \pm 40^{\circ} \mathrm{C}\right.$, Putirka 2008 ; $\pm 70{ }^{\circ} \mathrm{C}$; Wells 1977$)$ and clinopyroxene-olivine-plagioclase (COlP) $\left( \pm 20^{\circ} \mathrm{C}\right.$, Ziberna et al. 2017). Post entrapment crystallisation (PEC) effects preclude the use of mineralmelt thermometers. Major element data for touching rims and/or included phases and their adjacent hosts were used in all thermometer calculations to ensure textural equilibrium. Blundy and Cashman (2008) demonstrated that pressure has a modest dependence on thermometry $\left( \pm 72{ }^{\circ} \mathrm{C} \mathrm{GPa}^{-1}\right)$ at sub-volcanic pressures. Therefore, where a pressure estimate was necessary for thermometry, a nominal value of $500 \mathrm{MPa}$ was applied. The olivine-spinel Fe-Mg exchange thermometer is only applicable at high Cr\#. Due to the infrequency of Cr-spinel, appropriate co-existing phases were available in only one sample (BQA3). Temperature estimates for coexisting oxide pairs were made using the ILMAT program of LePage (2003) with Lindsley and Spencer (1982) method for recalculation. The hornblende-plagioclase thermometer is only valid if plagioclase is less calcic than $\mathrm{An}_{90}$ (Holland and Blundy 1994). Five samples (BQ8, BQA6, BQA18, BQA40, BQB11) contained plagioclase with higher An, so their temperatures are underestimates.

Magma storage pressures were estimated by applying the solubility model of Ghiorso and Gualda (2015) to volatile saturation contents $\left(\mathrm{H}_{2} \mathrm{O}\right.$ and $\left.\mathrm{CO}_{2}\right)$ from xenolith $\mathrm{MI}$ at an assumed temperature of $950{ }^{\circ} \mathrm{C}$. If melts are undersaturated, or have lost $\mathrm{CO}_{2}$ to shrinkage bubbles, then these estimates are minima. Pressures were also calculated by the multiple reaction approach of Ziberna, et al. (2017) using COIP and spinel-clinopyroxene-olivine-plagioclase (SCOIP) assemblages. Two oxybarometers were evaluated in relation to the NNO buffer (Andersen and Lindsley 1985; Ballhaus et al. 1991).

Xenolith equilibration temperatures from all available methods are in the range $623-1055^{\circ} \mathrm{C}$, with the majority in the range $950-1050{ }^{\circ} \mathrm{C}$ (Fig. 10). Plagioclase-amphibole temperatures show good agreement between samples $\left(938-1044{ }^{\circ} \mathrm{C}\right.$ ) with the exception of BQA10 (Table 5). The broad temperature range (spanning $356{ }^{\circ} \mathrm{C}$ ) for this more evolved sample is interpreted to result from protracted crystallization. If this sample is omitted, there is an apparent progressive reduction in plagioclase-amphibole temperatures from Group 2 to 5 (Fig. 10). Similarly, using the COlP thermometer, Group 1 has higher crystallisation temperatures than Groups 5 and 6. Spinel-ilmenite phases exhibit low temperatures $\left(812-849^{\circ} \mathrm{C}\right)$ due to their ready re-equilibration with the melt.

MI were trapped over a pressure range of $160-570 \mathrm{MPa}$ (Fig. 11; Table 3) equivalent to 6-21 km vertical depth within the crust (assuming a density of $2750 \mathrm{~kg} / \mathrm{m}^{3}$ ). Because the presence of vapour bubbles in MI precludes the unequivocal establishment of original $\mathrm{CO}_{2}$ contents, these are minimum magma crystallisation pressures. However, pressure calculations using Ziberna, et al. (2017) are in the range $220-440 \mathrm{MPa}( \pm 50 \mathrm{MPa})$, in agreement with MI pressures and supportive of volatile saturation with limited $\mathrm{CO}_{2}$ sequestration into bubbles. We believe that values obtained using the clinopyroxene-orthopyroxene barometer of Putirka (2008) overestimates crystallisation pressure largely because its large error $( \pm 280 \mathrm{MPa})$ embraces the pressure range being investigated (Ziberna et al. 2017). The preservation of MI with elevated water contents (4.6-7.8 wt\%) suggests that xenoliths were entrained and erupted rather quickly. Oxygen fugacity estimates (Andersen and Lindsley 1985; Ballhaus et al. 1991) range from 1.2 to $1.9 \log$ units above the NNO buffer.

\section{Constraints from phase petrology}

Additional constraints on $\mathrm{P}-\mathrm{T}-\mathrm{H}_{2} \mathrm{O}$ conditions of xenolith crystallization can be obtained from equilibrium

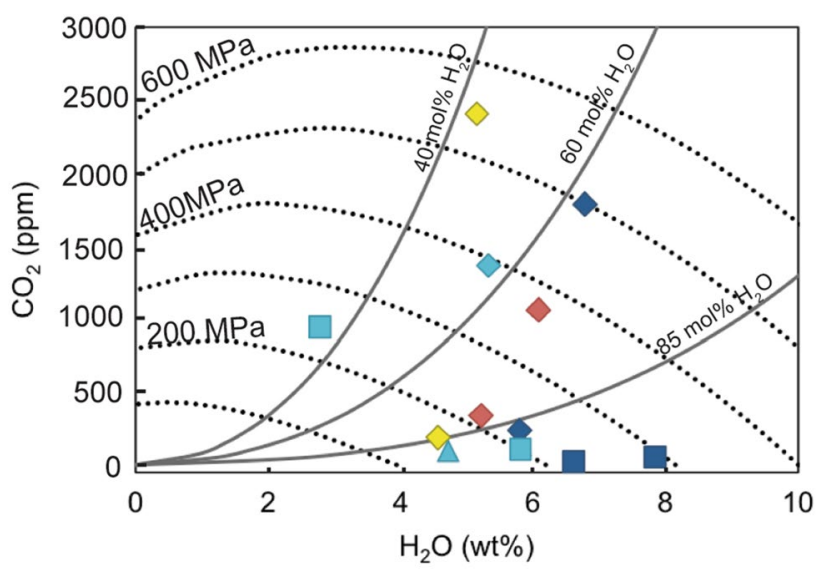

- Group 1 Group 2 Group 3 Group 5

Fig. 11 Volatile concentrations of $\mathrm{CO}_{2}$ and $\mathrm{H}_{2} \mathrm{O}$ in xenolith MI. Isobars and isopleths calculated for a representative MI using the MagmaSat solubility model (Ghiorso and Gualda 2015) at an assumed temperature of $950{ }^{\circ} \mathrm{C}$. MI host minerals denoted as follows: diamond, olivine; square, clinopyroxene; triangle, amphibole. Xenolith groups are distinguished by colour as shown in legend 
mineral assemblages and crystallisation sequences. This approach requires some insight into the nature of the parental magma(s) responsible for the observed xenoliths. The olivine Fo content (55-71) is inconsistent with a mantlederived parent, requiring instead some prior olivine $\pm \mathrm{cpx}$ fractionation, whereas the elevated An content of plagioclase is suggestive of a hydrous, high-alumina basalt magma (Panjasawatwong et al. 1995; Sisson and Grove 1993). Inspection of available experimental data on starting materials similar to Bequia lavas reveals the closest match to mineral assemblages and compositions is provided by three experimental studies using Lesser Antilles starting materials: high-alumina basalt GW40 from Guadeloupe (Pichavant et al. 2018), basaltic andesite 031-22b from Martinique (Pichavant et al. 2002a) and low-magnesium basalt STV315 from St. Vincent (Pichavant and Macdonald 2007). In Fig. 9, these three starting compositions are compared to Bequia whole rock lava compositions, showing that they represent reasonable candidates for parental magmas.

The selected experiments were performed in the presence of a mixed $\mathrm{H}_{2} \mathrm{O}-\mathrm{CO}_{2}$ fluid over a pressure range of 200-1000 MPa and $f \mathrm{O}_{2}$ around $\mathrm{NNO}+2 \log$ units. Experimental temperatures $\left(950-1050{ }^{\circ} \mathrm{C}\right)$ match closely those obtained by geothermometry (Table 5). Experimental melts have $\mathrm{H}_{2} \mathrm{O}_{\text {melt }}$ contents of 4 to $10 \mathrm{wt} \%$, spanning the range measured in MI (Table 3). Experimental olivine compositions are $\mathrm{Fo}_{62-85}$, bracketing the range observed in the xenoliths (Fig. 2). Experimental plagioclase composition is $\mathrm{An}_{68-89}$ covering much of the range observed in the xenoliths with the exception of the very calcic plagioclase $\left(\mathrm{An}_{>90}\right)$. The conditions required for crystallisation of such calcic plagioclase were evidently not attained in the experiments, either because the starting materials had insufficient $\mathrm{Ca} / \mathrm{Na}$ ratio (Hamada and Fujii 2007; Panjasawatwong et al. 1995) or additional phases, such as Cl-rich aqueous fluids played a role in removing $\mathrm{Na}$ from the system (Johannes and Holtz 1991; Orville 1972).

Each Bequia xenolith assemblage can be matched to specific experimental conditions (Table A2, Online Resource 5) indicating that the xenoliths are consistent with crystallisation of hydrous low-magnesium and high-alumina basalts, and basaltic andesite. The restricted experimental conditions that match each assemblage (Table A2, Online Resource 5 ), suggests that there is a limited range of crustal conditions under which the xenolith assemblages can crystallise from reasonable parent magmas. In Fig. 12 we show the experimental phase assemblages on a pressure- $\mathrm{H}_{2} \mathrm{O}_{\text {melt }}$ diagram constructed at $1000 \pm 50{ }^{\circ} \mathrm{C}$ together with MI (Table 3) colour-coded according to the host xenolith mineral assemblage. The agreement between experiments, xenolith assemblages, multiple-reaction barometry (Table 5) and MI is striking. With the exception of the Group 6c xenoliths with the plagioclase-free assemblage clinopyroxene + amphibole, that is stable only at elevated pressures, and a single low$\mathrm{H}_{2} \mathrm{O}$ MI (omitted from Fig. 12), the combination of experiments and xenoliths indicates crystallisation at pressures of 180-570 MPa with $\mathrm{H}_{2} \mathrm{O}_{\text {melt }}$ of 4-8 wt\%. Assemblages containing hornblende correspond to higher $\mathrm{H}_{2} \mathrm{O}_{\text {melt }}$ consistent with the higher volatile contents of MI from hornblende-bearing samples (Table 3). Orthopyroxene-bearing assemblages are only stable at pressures of $\sim 400 \mathrm{MPa}$. Note that the observed mineral assemblages do not require $\mathrm{H}_{2} \mathrm{O}$-saturated melts, consistent with the presence of

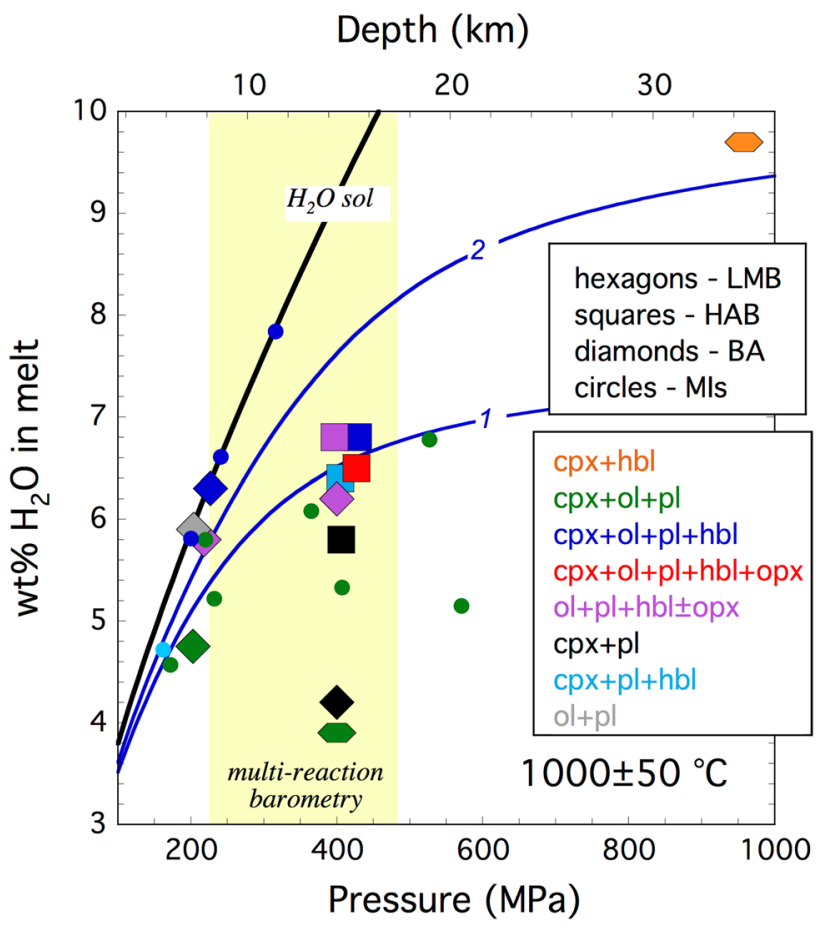

Fig. 12 Crystallisation conditions of Bequia xenoliths constrained by $\mathrm{MI}$ and experimental petrology in terms of wt $\% \mathrm{H}_{2} \mathrm{O}$ in melt and pressure at a temperature of $1000 \pm 50{ }^{\circ} \mathrm{C}$. Experimental run products for three Lesser Antilles starting materials that show the same mineral assemblages as Bequia xenoliths are plotted along with MI from Table 2 (a single low $\mathrm{H}_{2} \mathrm{O}$ MI is omitted for clarity). Symbols are colour-coded according to the relevant experimental mineral assemblage or that of the xenolith from which the MI derive. For experiments, the symbols correspond to the three different starting compositions (Fig. 9): low-magnesium basalt (LMB) STV315 (Pichavant and Macdonald 2007); high-alumina basalt (HAB) 031-22b (Pichavant et al. 2002a); basaltic andesite (BA) GW40 (Pichavant et al. 2018). $\mathrm{H}_{2} \mathrm{O}-\mathrm{CO}_{2}$ fluids and oxide minerals are present across the diagram, although the stability of individual oxides (magnetite, Cr-spinel, ilmenite) is sensitive to $f \mathrm{O}_{2}$, which varies from $\mathrm{NNO}$ to $\mathrm{NNO}+4 \log$ units for the plotted experiments. The $\mathrm{H}_{2} \mathrm{O}$ solubility curve is calculated using MagmaSat (Ghiorso and Gualda 2015) for a representative Bequia magma composition. The pressure range estimated from multiple reaction barometry (Table 5) is shown as a yellow bar. The two blue curves show degassing trends for the same representative Bequia magma with initial volatile contents of: (1) $7.5 \mathrm{wt} \% \mathrm{H}_{2} \mathrm{O}$ and $1 \mathrm{wt} \% \mathrm{CO}_{2}$; and (2) $10 \mathrm{wt} \% \mathrm{H}_{2} \mathrm{O}$ and $1 \mathrm{wt} \% \mathrm{CO}_{2}$, calculated using MagmaSat. The depth range on the upper horizontal axis was calculated for a density of $2750 \mathrm{~kg} \mathrm{~m}^{-3}$ 
significant $\mathrm{CO}_{2}$ in Bequia MI. We suggest instead that the xenoliths were formed by ascending basaltic magmas saturated in a mixed $\mathrm{H}_{2} \mathrm{O}-\mathrm{CO}_{2}$ fluid and crystallising at depths of 8-17 km. Degassing during ascent will progressively deplete the melts in $\mathrm{CO}_{2}$ relative to $\mathrm{H}_{2} \mathrm{O}$ as observed in the MI (Fig. 11). Thus, the spread of $\mathrm{H}_{2} \mathrm{O}_{\text {melt }}$ in Fig. 12 may reflect different degassing paths of a single basaltic parent, rather than batches with variable initial $\mathrm{H}_{2} \mathrm{O}$ contents. Two representative degassing trends are illustrated with blue curves (labelled 1 and 2) on Fig. 12. Note that both start at elevated $\mathrm{CO}_{2}$ contents ( $1 \mathrm{wt} \%$ ), to maintain fluid saturation throughout ascent. The residual melts produced during polybaric xenolith crystallisation is consistent with the observed Bequia liquid line of descent (Fig. 9). The rare clinopyroxene + amphibole assemblage (BQA20) may testify to even deeper $(1000 \mathrm{MPa} \approx 34 \mathrm{~km})$ crystallisation, plausibly close to the Moho. The texture of this xenolith (Fig. 4f) is suggestive of entrainment of a fragment deeper (plagioclase-free) xenolith material into melts that subsequently crystallise to a shallower (gabbroic) assemblage.

Xenolith crystallisation sequences have been shown to be quite variable (Table 1), notably the early or late appearance hornblende, olivine and plagioclase, sometimes in the same sample (Figs. 3, 4). This variability can be reconciled with the phase petrology constraints (Fig. 12) by considering different magma trajectories through the mid-crustal mush system. The late appearance of olivine and plagioclase can be produced in evolved basaltic magmas that ascend from sufficient depths that the first assemblage to crystallise is olivine- and plagioclase-free. In magmas that start to crystallise at lower pressures, olivine and/or plagioclase will be the first phase to crystallise. The later appearance of amphibole in many samples is consistent with isobaric addition of $\mathrm{H}_{2} \mathrm{O}$-rich fluids, moving the assemblage into the amphibole field in Fig. 12. The ability of different ascent and degassing paths through the crust to produce different crystallisation sequences, support the idea of extensive vertical and/or horizontal reach of volatile-rich melts through mush systems beneath Bequia.

\section{The role of amphibole}

The lack of amphibole from lavas, but its abundance in xenoliths, has led to amphibole being termed a 'cryptic' fractionating phase (Davidson et al. 2007). The textural and compositional variability of xenolith amphibole suggests that open system reactive flow is an important process facilitating its formation in crustal reservoirs. The percolation of external hydrous fluids (or melts) through a $\mathrm{H}_{2} \mathrm{O}$-poor mush may trigger the formation of amphibole, changing the composition of the melt as it flows upward. As for other systems (Smith 2014), it is assumed here that the fluids reacting with existing phases to form amphibole are not necessarily cogenetic in the strict sense that they did not form by protracted, in situ crystallization.

The melt compositions in equilibrium with calcic amphibole can be quantified using the chemometry method of Zhang, et al. (2017). Figure 9 shows that a wide diversity of melt compositions (60-75 wt\% $\mathrm{SiO}_{2}$ ) would have been present in amphibole-bearing xenoliths from Bequia. The most evolved xenolith, BQA10, yields as expected, the highest melt $\mathrm{SiO}_{2}$. Amphiboles in Group 2 give calculated melts with 61-65 wt $\% \mathrm{SiO}_{2}$ and 1.8-2.5 wt\% $\mathrm{MgO}$; Group 3 amphiboles give $61-72 \mathrm{wt} \% \mathrm{SiO}_{2}$ and $0.9-3.5 \mathrm{wt} \% \mathrm{MgO}$; Group 4 amphiboles give calculated melts spanning the entire $\mathrm{SiO}_{2}$ range for all groups and $0.4-3.8 \mathrm{wt} \% \mathrm{MgO}$; Group 5 amphiboles give calculated melts with $67-73 \mathrm{wt} \%$ $\mathrm{SiO}_{2}$ and $0.7-1.8 \mathrm{wt} \% \mathrm{MgO}$; and Group 6 amphiboles give calculated melts with $63-64 \mathrm{wt} \% \mathrm{SiO}_{2}$ and 2.7-3.0 wt $\%$ $\mathrm{MgO}$. The calculated melt compositions overlap with xenolith MI, but are not represented by any erupted magmas on Bequia (Fig. 9). The evolved nature of the trapped and calculated melts suggests that they are residual interstitial melts left over from the precipitation of hornblende.

One may question why amphibole is so glaringly absent from the lavas, yet so prevalent in deeper crustal xenoliths. Barclay and Carmichael (2004) suggest that the onset of rapid hornblende crystallisation in hydrous basaltic magmas will impede magma ascent by its associated increase in crystallinity. The eruptibility of such magmas is, therefore, reduced and may explain the paucity of amphibole-bearing erupted magmas at the surface. The tendency for amphibole to form reaction rims upon decompression may also increase its bulk density and impede its continued incorporation into ascending magmas at lower depths (Davidson et al. 2007). It is, therefore, unsurprising that lavas may show geochemical evidence for amphibole fractionation, if they represent melts extracted from amphibole-bearing mushes at depths of $>8 \mathrm{~km}$. We see no evidence for entrainment of individual amphibole crystals and their subsequent breakdown at lower pressures (Rutherford and Devine 1988; Rutherford and Hill 1993). The only evidence for amphibole-rich mush comes from the xenoliths that are presumably entrained and discharged sufficiently rapidly by explosive eruptions that amphibole is preserved. The preservation of high $\mathrm{H}_{2} \mathrm{O}$ in MI also testifies to rapid xenolith ascent and eruption.

\section{Xenocrysts, antecrysts or phenocrysts?}

Compositional and textural parallels between xenolith and lava mineral assemblages suggest that the entrainment of crustal mush fragments may be a significant process operating during lava extrusion on Bequia. One manifestation of mush entrainment could be the abundance of glomerocrysts in lavas. Glomerocrysts may form by synneusis: the drifting together and attachment of crystals suspended in the 
melt (Vance 1969; Vogt 1921). Alternatively, polymineralic glomerocrysts may have been sourced from cumulate piles underlying mush regions. On Bequia, mineral modes and chemistry suggest significant differences between glomerocrysts and xenoliths. Glomerocrysts have assemblages dominated by olivine and clinopyroxene with no sign of reacted amphiboles or their pseudomorphs (Fig. 2c). The abundance of olivine and clinopyroxene and the absence of amphibole and orthopyroxene in glomerocrysts suggest that they crystallized close to the liquid of melts with less than $4 \mathrm{wt} \% \mathrm{H}_{2} \mathrm{O}$ (Fig. 12). These are lower pressure conditions than those inferred for the xenoliths. We suggest that glomerocrysts are accumulations of near-liquidus minerals from these $\mathrm{H}_{2} \mathrm{O}$-saturated magmas (Fig. 12) en route to shallow crustal storage regions, where phenocrysts grow.

\section{Primitive mantle source}

Both lavas and xenoliths contain mineralogical evidence for primitive melts influencing differentiation processes beneath Bequia. Although less magnesian than Grenadian olivine phenocrysts $\left(\mathrm{Fo}_{91-73}\right.$ Stamper et al. 2014a), some olivine phenocrysts in Bequia lavas exhibit primitive compositions of $\mathrm{Fo}_{\leq 84}$ which are more magnesian than xenolith olivines (Fig. 6), but contain significantly less Ni. Comparatively high $\mathrm{Cr}$ contents are found in spinel and amphibole analyses from specific cumulate groups providing evidence for a primitive mantle source. Xenolith Groups 1, 2 and 6 along with some phenocrysts contain Cr-rich spinels $(\mathrm{Cr} \#>40)$ (Figure A2, Online Resource 3). Amphibole from Groups 2 and 6 exhibits comparatively high Cr contents with correspondingly high Mg\#. Highly magnesian cores (Mg\# $\left.{ }_{100-90}\right)$ are also observed in augite phenocrysts, glomerocrysts and Group 1 xenoliths (Fig. 7). These have been proposed by Thirlwall and Graham (1984) for Grenada C-series basalts as remnants of lavas generated from picritic basalt precursors not seen at the surface. In Bequia, these examples may be relicts of primitive melts emplaced into the deeper magmatic system. Early precipitation of olivine \pm clinopyroxene will drive the residual melts to low-MgO and high-alumina basalt compositions responsible for some of the observed xenolith assemblages. There are no wehrlitic Bequia xenoliths that record this early, presumably deep, crystallisation. We suggest that they are confined to the lower crust.

\section{Southern arc segment comparisons}

Differences in melt compositions and conditions of crystallisation in the southern segment of the Lesser Antilles arc are clearly demonstrated in cumulate compositions and textures from constituent volcanic islands (Table A3, Online Resource 6). There is an apparent northward reduction in compositional primitiveness $(\mathrm{Fo}, \mathrm{An})$ of xenoliths from Grenada to St. Vincent. Grenada contains the only extensive suite of plagioclase-free cumulates in the entire Lesser Antilles arc (Arculus and Wills 1980), while Bequia and St. Vincent cumulates are dominated modally by plagioclase. Similarly, ultramafic cumulates such as wehrlites and pyroxenites are present in Grenada, but only present as rare plagioclase-bearing pyroxenites in Bequia and St. Vincent (Figure A4, Online Resource 7). Troctolites are absent in Grenada, but present in Bequia and (abundantly) in St. Vincent. Cumulate amphibole is dominant in Grenada and substantial in Bequia, but less prevalent in St. Vincent. Grenadian olivine compositions are the most magnesian with higher Ni contents than Bequia and St. Vincent. Bequia xenoliths, however, show the lowest Fo contents amongst the three islands, suggesting significant depletion of $\mathrm{MgO}$ prior to crystallization of the xenoliths. Cr-rich spinels are absent from St. Vincent xenoliths, but present in Bequia and Grenada, with the latter having a higher $\mathrm{Cr} \#$ and greater proportion. The iddingsitized nature of olivine in Grenada and Bequia versus its unaltered appearance in St. Vincent may be a reflection of the northward decrease in water content in the mantle source from Grenada to St. Vincent, as alluded to by Stamper, et al. (2014a).

Clinopyroxene $\mathrm{Ca}$ compositions in the lavas highlight two series distinguished by the rate of $\mathrm{Ca}$ depletion with

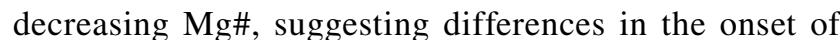
clinopyroxene crystallisation (Fig. 7). This is reminiscent of the $\mathrm{M}$ - and $\mathrm{C}$-series lavas of Grenada whose $\mathrm{CaO}$ versus $\mathrm{MgO}$ whole rock contents show two separate liquid lines of descent (Stamper et al. 2014a), attributed to variations in the differentiation depth of a common picritic parent (Stamper et al. 2014b). A geochemical boundary between St. Vincent and the Grenadines has been suggested by Macdonald, et al. (2000) on the basis of the restriction of M- and C- series rocks to the southern part of this arc segment. However, an observation scarcely mentioned in the literature is the presence of M- and C- series lavas in St. Vincent, which is clearly observed when $\mathrm{CaO}$ versus $\mathrm{MgO}$ whole rock data from GEOROC are plotted (Fig. 13c). For the most part, however, bulk rock lava and MI geochemical data show that Bequia exhibits transitional affinities between St. Vincent and Grenada, with a few exceptions (Fig. 13). For example, the $\mathrm{Al}_{2} \mathrm{O}_{3}$ versus $\mathrm{MgO}$ trend on Bequia describes a more pronounced peak in $\mathrm{Al}_{2} \mathrm{O}_{3}$, while the $\mathrm{MgO}$ content of Bequia lavas are $<11 \mathrm{wt} \%$, whereas St. Vincent and Grenada lavas extend beyond $15 \mathrm{wt} \% \mathrm{MgO}$. In fact, Bequia data appear to fill the gap in $\mathrm{MgO}$ content that distinguishes the $\mathrm{M}$ - and C- series (Fig. 13a, c).

When cumulate textures are compared amongst the three islands, Bequia is markedly different from Grenada and St. Vincent where cumulates display chiefly adcumulate textures, consistent crystallisation sequences (phases always crystallising in the same order), minimal zoning and 

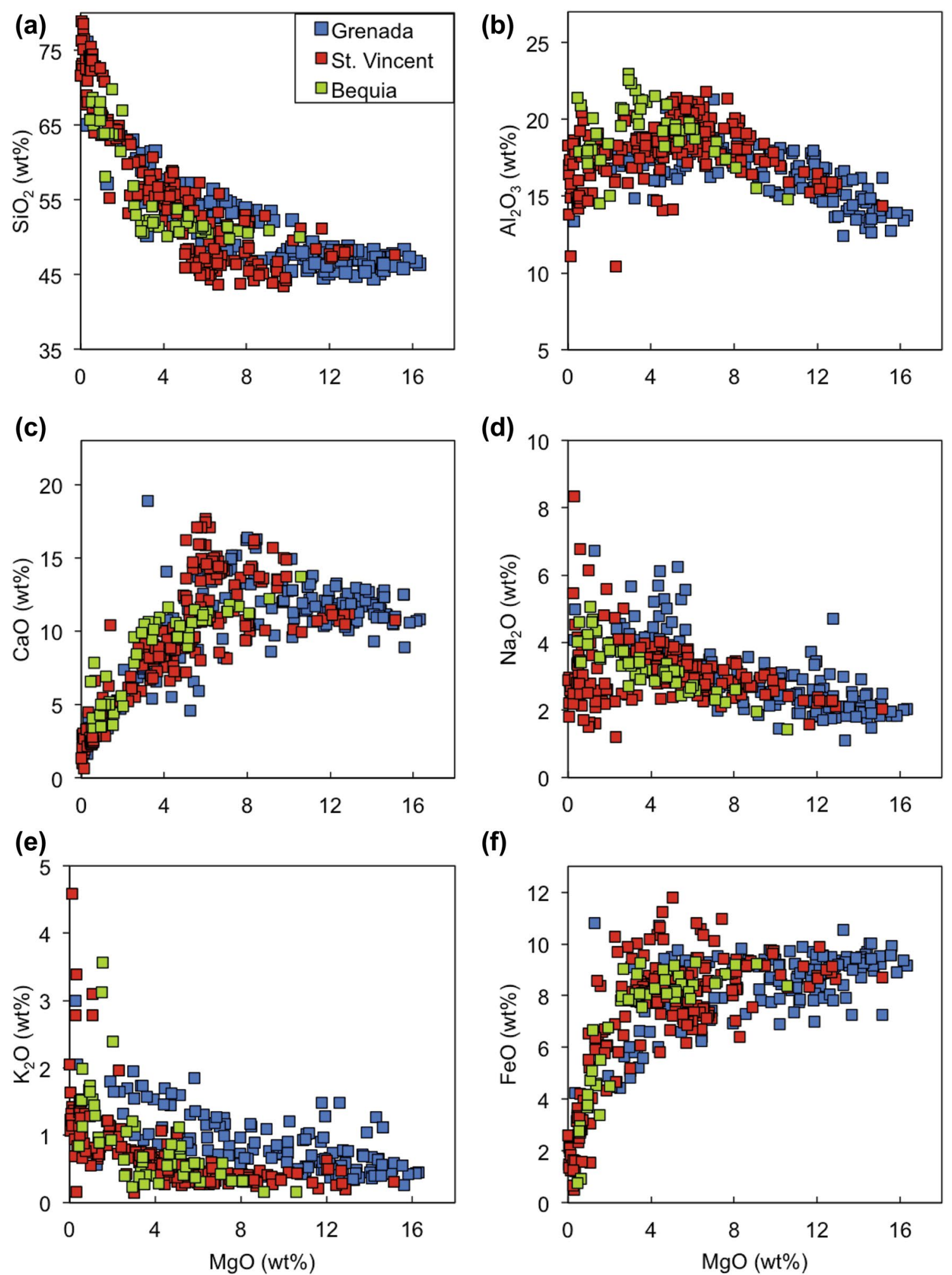

Fig. 13 Bulk major element variations in lavas and MI from Grenada, St. Vincent and Bequia. Data are obtained from GEOROC database

narrow mineral compositional ranges (Table A3, Online Resource 6). Bequia cumulates, in contrast, show evidence for persistent disequilibria and crystallization over a much broader range of $\mathrm{P}-\mathrm{T}-\mathrm{H}_{2} \mathrm{O}$ conditions (Fig. 12). Although all three islands contain gabbro xenoliths (Figure A4, Online Resource 7), on St. Vincent and Grenada these belong to just 
two and one textural sub-divisions (according to Steckeisen 1976), respectively; Bequia contains eleven varieties of gabbros as well as gabbronorites (Table 1). These observations, combined with widespread mineral zoning, substantial proportions of xenoliths with orthocumulate textures, variable crystallisation sequences, pervasive sieve textured plagioclase and broad compositional phase ranges, emphasize different conditions in the mush pile beneath the three islands. Textural similarities between Grenada and St. Vincent xenoliths may be related to the stability of the magmatic systems beneath these two islands facilitating the establishment of long-lived volcanism. Conversely, the relatively small size of Bequia may not have supported the protracted development of a large magmatic reservoir, such that cumulates form and melts are extracted over a wider range of conditions between which there appear to be periods of re-equilibration and exchange.

\section{Bequia plumbing system}

Magmatic processes in Bequia operate over a wide depth range (6 to at least $21 \mathrm{~km}$ ) in the crust (Fig. 14) in what has been termed a transcrustal magmatic system (TCMS) by Cashman, et al. (2017). Xenolith crystallisation pressures indicate that a vertically-extensive crystal mush (crystals + melt) enables polybaric differentiation to occur in a hot zone extending from near the Moho to the upper crust (Melekhova et al. 2015). This hot zone also contains elevated $\mathrm{H}_{2} \mathrm{O}$ contents in trapped melts, lending support to the idea of a hydrous mush dominated by amphibole (Davidson et al. 2007). Several lines of evidence suggest that volatile-charged low-magnesium and high-alumina basalt and basaltic andesite magmas stall at different depths through the TCMS (Fig. 14) resulting in reaction to produce new phases: e.g. early and late crystallising hornblende, variable crystallisation sequences, zoning, layered lithologies, broad mineral compositional ranges and extensive crystallisation temperature ranges. The source of such melts may be from different parent magmas and/or the same melt at different stages of evolution, percolating the mush and effectively modulating the conditions of the system. Similar open system processes were noted from plutonic xenoliths in Martinique (Cooper et al. 2016). These basaltic compositions are products of prior crystallisation of mantle-derived magmas. The olivine \pm clinopyroxene cumulates formed during this differentiation step are not preserved on Bequia, yet plausibly constitute much of its lower crust.

A wide, mid-crustal depth range of crystallisation is supported by the calculated pressures from melt inclusions, thermobarometry and phase petrology (Figs. 11, 12 and Table A2, Online Resource 5). The presence of an amphibole-free group implies that some mush regions

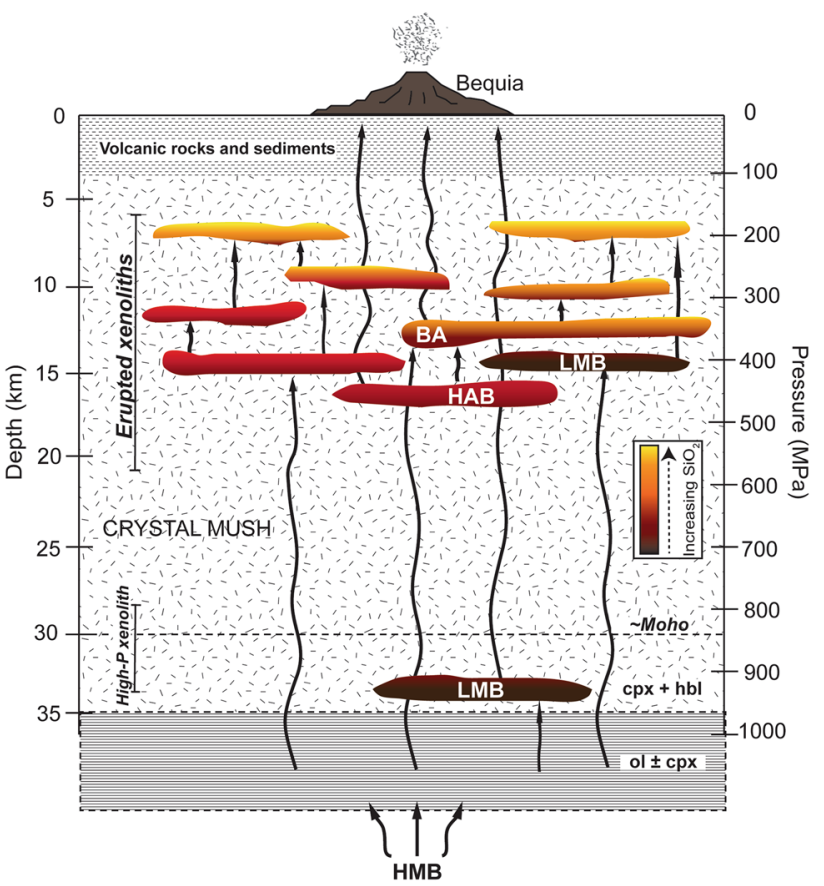

Fig. 14 Schematic diagram to illustrate the plumbing system beneath Bequia based on the agreement between phase petrology, thermobarometry and melt inclusions. Labelled fields denote $\mathrm{P}$ regions from which xenoliths (mush fragments) are sourced and low-magnesium basalts (LMB), high-alumina basalts (HAB) and basaltic andesites (BA) stall and differentiate. These basaltic compositions are the products of prior differentiation of mantle-derived high-magnesium basalts (HMB). Colours indicate the $\mathrm{SiO}_{2}$ content of the melts. Arrows show the ascent and differentiation of melts from different regions within the crust

may have been $\mathrm{H}_{2} \mathrm{O}$-poor, lending support to the idea of substantial horizontal variability within the TCMS. Such lateral variability is consistent with along-arc geophysical studies of the Antilles that show considerable variability in P-wave structure on wavelengths of several tens of kilometres (Boynton et al. 1979). It is no surprise that a layered cumulate group was identified with texturally different lithologies juxtaposed next to each other at the microscopic scale, possibly due to entrainment of earlier assemblages into later magmas. Similar textures have been observed elsewhere in plutonic xenoliths (Tollan et al. 2011).

Although Bequia xenoliths have assemblages and crystallization sequences consistent with differentiation of hydrous mafic magmas over a broad depth range, melt compositions in these samples are significantly more evolved than erupted lavas. The failure of such evolved melts to segregate and erupt on Bequia suggests that the mush never attained sufficient size or that melt extraction was inefficient, in comparison to islands north of St. Vincent, where evolved melts are commonplace (Macdonald et al. 2000). These observations support the idea of a TCMS containing vertically 
connected lenses of fractionated melt segregated from dense mafic cumulates, which migrate upwards finally combining to form magma reservoirs at physically favourable depths (Christopher et al. 2015). Beneath Bequia, these lenses may never have attained significant thicknesses. Eruption, which may be triggered by destabilization of the TCMS, allows melts from different depths to mix together and incorporate fragments (xenoliths) of surrounding crystal-dominated mush with different crystallisation histories. During ascent, $\mathrm{H}_{2} \mathrm{O}$-saturated crystallization of extracted melts leads to the formation of liquidus phenocryst assemblages and glomerocrysts that differ from those of the mush from which they were extracted, notably in the absence of amphibole and predominance of olivine. The tendency of melts extracted from mushes to produce characteristic, low-pressure phenocryst assemblages effectively obscures conditions within the mid-crustal mush. The study of both extrusive and plutonic (xenolith) samples helps to reconcile this discrepancy.

Acknowledgements This research was supported by a Commonwealth Scholarship to MC-H, funded by the UK government and a NERC grant NE/N001966/1 to EM and JB. We thank Stuart Kearns for help with EPMA, Richard Hinton for assistance with SIMS and Jenni Barclay for facilitating XRF analysis. We thank Richard Arculus, Susanne Skora, Charlotte Stamper and Mikel Diez for help during sample collection. This work has benefitted from useful discussions with Kathy Cashman about glomerocrysts. Constructive reviews by Saskia Erdmann and Peter Ulmer, and the editorial handling of Othmar Müntener are gratefully acknowledged.

Open Access This article is distributed under the terms of the Creative Commons Attribution 4.0 International License (http://creativeco mmons.org/licenses/by/4.0/), which permits unrestricted use, distribution, and reproduction in any medium, provided you give appropriate credit to the original author(s) and the source, provide a link to the Creative Commons license, and indicate if changes were made.

\section{References}

Andersen DJ, Lindsley DH (1985) New (and final!) models for the Timagnetite/ilmenite geothermometer and oxygen barometer. Spring Meeting EoS Transactions American Geophysical Union 66(18)

Arculus RJ (1994) Aspects of magma genesis in arcs. Lithos 33:189-208

Arculus RJ, Wills KJA (1980) The petrology of plutonic blocks and inclusions from the Lesser Antilles island arc. J Petrol 21(4):743-799

Arnaiz-Rodriguez MS, Orihuela N (2013) Curie point depth in Venezuela and the Eastern Caribbean. Tectonophysics 590:38-51. https://doi.org/10.1016/j.tecto.2013.01.004

Attridge W (2013) The magmatic history of the Bequia Cumulates, Lesser Antilles, West Indies. Geology MSci Thesis. Univeristy of Bristol

Ballhaus C, Berry RF, Green DH (1991) High pressure experimental calibration of the olivine-orthopyroxene-spinel oxygen geobarometer: implications for the oxidation state of the upper mantle. Contrib Miner Petrol 107:27-40

Barclay J, Carmichael ISE (2004) A Hornblende Basalt from Western Mexico: Water-saturated Phase Relations Constrain a
Pressure-Temperature Window of Eruptibility. J Petrol 45(3):485506 (0.1093/petrology/egg091)

Blundy J, Cashman K (2005) Rapid decompression-driven crystallization recorded by melt inclusions from Mount St. Helens volcano. Geology 33(10):793-796. https://doi.org/10.1130/G21668.1

Blundy J, Cashman K (2008) Petrologic Reconstruction of Magmatic System Variables and Processes. Rev Mineral Geochem 69:179_ 239. https://doi.org/10.2138/rmg.2008.69.6

Boynton CH, Westbrook GK, Bott MHP, Long RE (1979) A seismic refraction investigation of crustal structure beneath the Lesser Antilles island arc. Geophys J Roy Astron Soc 58:371-393

Briden JC, Rex DC, Faller AM, Tomblin JF (1979) K-Ar geochronology and palaeomagnetism of volcanic rocks in the lesser Antilles Island Arc. Philos Trans R Soc Lond Ser A Math Phys Sci 291(1383):485-528. https://doi.org/10.2307/75166

Brown GM, Holland JG, Sigurdsson H, Tomblin JF, Arculus RJ (1977) Geochemistry of the lesser Antilles Volcanic Island Arc. Geochim Cosmochim Acta 41:785-801

Cashman KV, Sparks RSJ, Blundy JD (2017) Vertically extensive and unstable magmatic systems: a unified view of igneous processes. Science 355:3055. https://doi.org/10.1126/0.1126/science.aag30 55

Christeson GL, Mann P, Escalona A, Aitken TJ (2008) Crustal structure of the Caribbean-northeastern South America arc-continent collision zone. J Geophys Res 113:B08104. https://doi. org/10.1029/2007JB005373

Christopher TE, Blundy J, Cashman K, Cole P, Edmonds M, Smith PJ, Sparks RSJ, Stinton A (2015) Crustal-scale degassing due to magma system destabilization and magma-gas decoupling at Soufriere Hills Volcano, Montserrat. Geochemisty, Geophys Geosyst 16:2797-2811 https://doi.org/10.1002/2015GC005791

Cooper GF, Davidson JP, Blundy JD (2016) Plutonic xenoliths from Martinique, Lesser Antilles: evidence for open system processes and reactive melt flow in island arc crust. Contrib Miner Petrol https://doi.org/10.1007/s00410-016-1299-8

Davidson JP, Turner S, Handley H, Macpherson C, Dosseto A (2007) Amphibole "sponge" in arc crust? Geology 35:787-790. https:// doi.org/10.1130/G23637A.1

Deer WA, Howie RA, Zussman J (2013) An Introduction to the RockForming Minerals. The Mineralogical Society, London

Droop GTR (1987) A general equation for estimating Fe 3 + concentrations in ferromagnesian silicates and oxides from microprobe analyses, using stoichiometric criteria. Mineral Mag 51:431-435

Gavrilenko M, Herzberg C, Vidito C, Carr MJ, Tenner T, Ozerov A (2016) A calcium-in-olivine geohygrometer and its application to subduction zone magmatism. J Petrol 57(9):1811-1832. https ://doi.org/10.1093/petrology/egw062

Ghiorso MS, Gualda GAR (2015) An $\mathrm{H}_{2} \mathrm{O}-\mathrm{CO}_{2}$ mixed fluid saturation model compatible with rhyolite-MELTS. Contrib Miner Petrol 169:1-30

Hamada M, Fujii N (2007) $\mathrm{H}_{2} \mathrm{O}$-rich island arc low-K tholeiite magma inferred from $\mathrm{Ca}$-rich plagioclase-melt inclusion equilibria. Geochem J 41:437-461

Hasanie RA (2000) Crystallization porcesses, geothermometry and geobarometry of the volcanic blocks of Bequia, Lesser Antilles. University of Windsor, Windsor

Heath E, Macdonald R, Belkin H, Hawkesworth CJ, Sigurdsson H (1998) Magmagenesis at Soufriere Volcano, St Vincent, Lesser Antilles Arc. J Petrol 39(10):1721-1764

Holland T, Blundy J (1994) Non-ideal interactions in calcic amphiboles and their bearing on amphibole-plagioclase thermometry. Contrib Miner Petrol 116(4):433-447

Howe TM, Lindsay JM, Shane P (2015) Evolution of young andesitic-dacitic magmatic systems beneath Dominica, Lesser Antilles. J Volcanol Geoth Res 297:69-88. https://doi. org/10.1016/j.jvolgeores.2015.02.009 
Humphreys MCS, Kearns S, Blundy JD (2006) SIMS investigation of electron-beam damage to hydrous, rhyolitic glasses: implications for melt inclusion analysis. Am Miner 91:667-679

Johannes W, Holtz F (1991) Melting of plagioclase in granite and related systems - composition of coexisting phases and kinetic observations. In: Brown PE, Chappell BW (eds) The Second Hutton Symposium on the Origin of Granites and Related Rocks

Kohler TP, Brey GP (1990) Calcium exchange between olivine and clinopyroxene calibrated as a geothermobarometer for natural peridotites from 2 to $60 \mathrm{~kb}$ with applications. Geochim Cosmochim Acta 54:2375-2388

Kopp H, Weinzierl W, Becel A, Charvis P, Evain M, Flueh ER, Gailler A, Galve A, Hirn A, Kandilarov A, Klaeschen D, Laigle M, Papenberg C, Planert L, Roux E (2011) Deep structure of the central Lesser Antilles Island Arc: relevance for the formation of continental crust. Earth Planet Sci Lett 304(1-2):121-134. https://doi.org/10.1016/j.epsl.2011.01.024

Leake BE, Woolley AR, Birch WD, Burke EAJ, Ferraris G, Grice JD, Hawthorne FC, Kisch HJ, Krivovichev VG, Schumacher JC, Stephenson NCN, Wittaker EJW (2003) Nomenclature of amphiboles: additions and revisions to the international mineralogical association's 1997 recommendations. Can Mineral 41:1355-1362

LePage LD (2003) ILMAT: an excel worksheet for ilmenite-magnetite geothermometry and geobarometry. Comput Geosi 29:673-678

Lewis JF (1973) Mineralogy of the ejected plutonic blocks of the Soufriere volcano St. Vincent: olivine, pyroxene, amphibole and magnetite paragenesis. Contrib Miner Petrol 38:197-220

Lindsay JM, Robertson REA, Shepherd JB, Ali S (2005) Volcanic Hazard Atlas of the Lesser Antilles. In, vol. Seismic Research Unit, The University of the West Indies, Trinidad

Lindsley DH, Spencer KJ (1982) Fe-Ti oxide geothermometry: Reducing analyses of coexisting Ti-magnetite (Mt) and ilmenite (Ilm). EoS Transactions, American Geophysical Union 63:471

Macdonald R, Hawkesworth C, Heath E (2000) The Lesser Antilles volcanic chain: a study in arc magmatism. Earth Sci Rev 49(14):1-76. https://doi.org/10.1016/S0012-8252(99)00069-0

Melekhova E, Blundy J, Robertson R, Humphreys MCS (2015) Experimental evidence for polybaric differentiation of primitive Arc Basalt beneath St. Vincent, Lesser Antilles. J Petrol 56(1):161192. https://doi.org/10.1093/petrology/egu074

Melekhova E, Blundy J, Martin R, Arculus R, Pichavant M (2017) Petrological and experimental evidence for differentiation of waterrich magmas beneath St. Kitts, Lesser Antilles. Contrib Miner Petrol 172(98) https://doi.org/10.1007/s00410-017-1416-3

Moore LR, Gazel E, Tuohy R, Lloyd AS, Esposito R, Steele-MacInnis M, Hauri EH, Wallace PJ, Plank T, Bodnar J (2015) Bubbles matter: An assessment of the contribution of vapor bubbles to melt inclusion volatile budgets. Am Miner 100:806-823 doi. https:// doi.org/10.2138/am-2015-5036

Munday D, Thirlwall M, Smith T (2000) Isotopic Variation in Cumulate Xenoliths from Bequia, Lesser Antilles. In: Goldschmidt 2000, vol 5. Cambridge Publications, Oxford, p 730

Müntener O, Kelemen PB, Grove TL (2001) The role of H2O during crystallization of primitive arc magmas under uppermost mantle conditions and genesis of igneous pyroxenites: an experimental study. Contrib Miner Petrol 141:643-658. https://doi.org/10.1007/ s004100100266

Nielsen SG, Marschall HR (2017) Geochemical evidence for mélange melting in global arcs. Sci Adv 3(4):e1602402

Orville PM (1972) Plagioclase cation exchange equilibria with aqueous chloride solution: results at $700{ }^{\circ} \mathrm{C}$ and 2000 bars in the presences of quartz. Am J Sci 272:234-272

Panjasawatwong Y, Danyushevsky LV, Crawford AJ, Harris KL (1995) An experimental study of the effects of melt composition on plagioclase-melt equilibria at 5 and 10 kbar: implications for the origin of magmatic high-An plagioclase. Contrib Mineral Petrol 118(4):420-432 doi. https://doi.org/10.1007/s004100050024

Pearce JA, Peate DW (1995) Tectonic implications of the composition of volcanic arc magmas. Annu Rev Earth Planet Sci 24:251-285

Pichavant M, Macdonald R (2007) Crystallization of primitive basaltic magmas at crustal pressures and genesis of the calc-alkaline igneous suite: experimental evidence from St Vincent, Lesser Antilles arc. Contrib Miner Petrol 154(5):535-558. https://doi. org/10.1007/s00410-007-0208-6

Pichavant M, Martel C, Bourdier J-L, Scaillet B (2002a) Physical conditions, structure, and dynamics of a zoned magma chamber: Mount Pelee (Martinique, Lesser Antilles Arc). J Geophys Res 107(B5):2093. https://doi.org/10.1029/2001JB000315

Pichavant M, Mysen BO, Macdonald R (2002b) Source and H2O content of high-MgO magmas in island arc settings: an experimental study of a primitive calc-alkaline basalt from St. Vincent, Lesser Antilles arc. Geochim Cosmochim Acta 66(12):2193-2209

Pichavant M, Poussineau S, Lesne P, Solaro C, Bourdier J-L (2018) Experimental parametrization of magma mixing: application to the AD 1530 Eruption of La Soufriere, Guadeloupe (Lesser Antilles). J Petrol 59(2):257-282. https://doi.org/10.1093/petrology/ egy030

Putirka KD (2008) Thermometers and barometers for volcanic systems. Rev Mineral Geochem 69(1):61-120. https://doi.org/10.2138/ rmg.2008.69.3

Roeder PL, Emslie RF (1970) Olivine-liquid equilibrium. Contrib Miner Petrol 29:275-289

Rutherford MJ, Devine JD (1988) The May 18, 1980. eruption of Mount St. Helens. 3. Stability and chemistry of amphibole in the magma chamber. J Geophys Res 93(B10):11949-11959

Rutherford MJ, Hill PM (1993) Magma ascent rates from amphibole breakdown: An experimental study applied to the 1980-1986 Mount St. Helens eruptions. J Geophys Res 98(B11):19667-19685

Seaman SJ (2000) Crystal clusters, feldspar glomerocrysts, and magma envelopes in the Atascosa Lookout lava flow, Southern Arizona, USA: Recorders of magmatic events. J Petrol 41(5):693-716

Shejwalkar A, Coogan LA (2013) Experimental calibration of the roles of temperature and composition in the Ca-in-olivine geothermometer at 0.1 MPa. Lithos 177:54-60

Sisson TW, Grove TL (1993) Experimental investigations of the role of $\mathrm{H} 2 \mathrm{O}$ in calc-alkaline differentiation and subduction zone magmatism. Contrib Miner Petrol 113(2):143-166. https://doi. org/10.1007/BF00283225

Smith DJ (2014) Clinopyroxene precursors to amphibole sponge in arc crust. Nat Commun 5:4329. https://doi.org/10.1038/ncomms5329

Smith TE, Thirlwall MF, Macpherson C (1996) Trace element and isotope geochemistry of the volcanic rocks of Bequia, Grenadine Islands, Lesser Antilles Arc: a study of subduction enrichment and intra-crustal contamination. J Petrol 37:117-143. https://doi. org/10.1093/petrology/37.1.117

Stamper CC, Blundy JD, Arculus RJ, Melekhova E (2014a) Petrology of plutonic xenoliths and volcanic rocks from Grenada, Lesser Antilles. J Petrol 55(7):1353-1387. https://doi.org/10.1093/petro logy/egu027

Stamper CC, Melekhova E, Blundy JD, Arculus RJ, Humphreys MCS, Brooker RA (2014b) Oxidised phase relations of a primitive basalt from Grenada, Lesser Antilles. Mineral Petrol https://doi. org/10.1007/s00410-013-0954-6

Steckeisen A (1976) To each plutonic rock its proper name. Earth-Sci Rev 12:1-33

Thirlwall MF, Graham AM (1984) Evolution of high-Ca, high-Sr C-series basalts from Grenada, Lesser Antilles: the effects of intra-crustal contamination. J Geol Soc London 141:427-445

Tollan PME, Bindeman I, Blundy JD (2011) Cumulate xenoliths from St. Vincent, Lesser Antilles Island Arc: a window into 
upper crustal differentiation of mantle-derived basalts. Contrib Miner Petrol 163(2):189-208. https://doi.org/10.1007/s0041 0-011-0665-9

Toothill J, William CA, Macdonald R, Turner SP, Rogers NW, Hawkesworth CJ, Jerram DA, Ottley CJ, Tindle AG (2007) A Complex Petrogenesis for an Arc Magmatic Suite, St Kitts, Lesser Antilles. J Petrol 48(1):3-42 doi. https://doi.org/10.1093/petrology/eg1052 Vance JA (1969) On synneusis. Contrib Miner Petrol 24:7-29

Vogt JHL (1921) The physical chemistry of the crystallization and magmatic differentiation of the igneous rocks. J Geol 29:318-350

Wager LR, Brown GM, Wadsworth WJ (1960) Types of igneous cumulates. J Petrol 1(1):73-85. https://doi.org/10.1093/petrology/1.1.73

Wells PRA (1977) Pyroxene thermometry in simple and complex systems. Contrib Miner Petrol 62:129-139
Westercamp D, Andreieff P, Bouysse P, Mascle A, Baubron JC (1985) Geologie de l'archipel des Grenadines (Petites Antilles meridionales). Etude monographique, vol 92. Documents du Bureau de Recherches Geologiques et Minieres, Orleans, p 198

Zhang J, Humphreys MCS, Cooper GF, Davidson JP, Macpherson CG (2017) Magma mush chemistry at subduction zones, revealed by new melt major element inversion from calcic amphiboles. Am Mineral 102:1353-1367. https://doi.org/10.2138/am-2017-5928

Ziberna L, Green ECR, Blundy JD (2017) Multiple-reaction geobarometry for olivine-bearing igneous rocks. Am Mineral https://doi. org/10.2138/am-2017-6154 